\title{
The Contact uranium prospect, Kiggavik project, Nunavut (Canada): tectonic history, structural constraints and timing of mineralization
}

\author{
Alexis Grare $^{\mathrm{a}, \mathrm{b}}$, Antonio Benedicto ${ }^{\mathrm{b}, \mathrm{c}}$, Olivier Lacombe ${ }^{\mathrm{a}}$, Anna Trave ${ }^{\mathrm{d}}$, Patrick Ledru ${ }^{\mathrm{b}}$, \\ Mario Blain ${ }^{\mathrm{b}}$, John Robbins ${ }^{\mathrm{b}}$, \\ a Sorbonne Universités, UPMC-CNRS-iSTeP, 4 place Jussieu. 75005 Paris. France \\ ${ }^{b}$ AREVA Resources Canada Inc. 817-45th St West Saskatoon. SK S7L 5X2. Canada \\ ${ }^{c}$ UMR Geops, Université Paris Sud, 91405 Orsay, France \\ ${ }^{d}$ Universitat de Barcelona (UB), Departament de Mineralogia, Petrologia i Geologia Aplicada, \\ Facultat de Ciències de la Terra. Carrer de Martí i Franquès s/n. 08028 Barcelona. Spain
}

\section{Abstract}

Uranium mineralization in the Kiggavik area, on the eastern border of the Thelon basin (Nunavut, Canada), hosts significant uranium resources within the basement and its understanding is critical to comprehending the genesis of unconformity-related deposits' structural controls and therefore exploration of these types of deposits in this prospective district. This article deciphers the complex multiphase fracture network associated with uranium mineralization of the most recently discovered, basement-hosted prospect in the Kiggavik area, named Contact. The Contact prospect is located along the Andrew Lake Fault (ALF), a major NE-SW fault corridor in the area. This study combines field work, drillcore logging, sampling, and macro- to micro- petro-structural analyses. Key results from this study highlight that the NEtrending ALF, along with the ENE-trending Thelon (TF) and Judge Sissons (JSF) faults, formed early during intracratonic rifting and deposition of the Baker Lake and Wharton groups (ca. 1850-1750 Ma) in response to the Thelon and Trans-Hudsonian orogeny. The ALF was affected by a strong silicification-brecciation event that likely developed at ca. $1750 \mathrm{Ma}$, and partitioned later deformation and fluid circulation. In the Contact prospect, the ALF was reactivated multiple times and mineralized in three stages with distinctive secondary fracture patterns, alteration, and mineralization types. Ten fracture stages have been identified at the Contact prospect, $\mathrm{f} 1$ to $\mathrm{f} 10$. The first stage of mineralization, coeval with $\mathrm{f5}$, is related to fluids of unconstrained origin that circulated through E-W faults in the area that locally re-activated quartz veins of the brecciation event at the intersection with the ALF. Mineralization at this stage is polymetallic and associated with weak clay alteration. The second stage of uranium 
mineralization occurred coeval with transtensional reactivation of the NE-SW trending ALF (f6c) and in relation to circulation of oxidizing basinal brines within the fault zone. Mineralization at this stage is monometallic and associated with illite and sudoite alteration. Later reactivation of the inherited fracture network (f8) led to strong illitization and bleaching of the host rock, with local reworking of the ore body. Finally, reactivation of the fracture network during $\mathrm{f} 9$ and 10 lead to circulation of meteoric fluids that remobilized mineralization in a third stage of uranium re-concentration along redox fronts, with strong illitization and bleaching of the host rock. Unlike the classic unconformity-related uranium deposits in the Athabasca Basin where clay alteration halos occur around the ore bodies related to mineralizing processes, in the Contact prospect the strongest clay alteration event (f8) postdates both main stages of mineralization. Along with uranium remobilization, the basement-hosted Contact prospect is likely a relict of what was once a larger deposit.

\section{Keywords}

Uranium deposit; alteration; structural control; fracture; Thelon Basin; Kiggavik.

\section{Introduction}

Unconformity-related uranium deposits are important because they are among the major uranium metal contributors in the world (OECD, NEA and IAEA, 2016). Such massive and high grade uranium deposits are found close to the unconformity between an Archean to Paleoproterozoic metamorphosed basement rocks and an overlying non-metamorphosed Paleoproterozoic sedimentary basin-infill (Dahlkamp, 1993). Major uranium deposits of this type are found in Canada, in the Athabasca Basin (i.e., the Cigar lake deposit, Dahlkamp, 1993; Jefferson et al., 2007), or in Australia, in the McArthur Basin (i.e., the Ranger deposit, Jaireth et al., 2016; Skirrow et al., 2016). The uranium ore is located within the basement (e.g. Eagle Point, Mercadier et al., 2011), at the unconformity (e.g. Cigar Lake, Bruneton, 1993) or perched within basin sandstones (e.g. Shea Creek, Sheahan et al., 2016). In both the Athabasca and the McArthur basins, the importance of structural control has been recognized (Hoeve and Quirt, 1984; Baudemont and Pacquet, 1996; Baudemont and Federowich, 1996; Tourigny et al., 2007; Jefferson et al., 2007; Kyser and Cuney, 2015). Uranium is linked to ductile to ductile-brittle shear zones in the Eagle Point (Mercadier et al., 2011), Nabarlek (Wilde and Wall, 1987), and Jabiluka (Polito et al., 2005a,b) deposits, to faults in the McArthur and Dominique-Peter deposits (Györfi et al., 2007; and Baudemont and Fedorowich, 1996; respectively), to breccias 
in the case of the Shea Creek deposit (De Veslud et al., 2009), and to a complex combination of folding and brecciation in the Jabiluka deposit (Polito et al., 2005a,b).

All this existing literature attributes a major role to shear zones, faults, and breccias in channeling metal-bearing fluids responsible for mineralization in unconformity-related uranium deposits, but none of these studies describes in detail the multi-scale organization of the mineralized fracture network and replaces it into the often long, polyphase and complex tectonic history. For instance, Dieng et al. (2013) reported the most complete review of the tectonic and uranium mineralizing events in the uraniferous Beaverlodge area (north-west of the Athabasca Basin), but they did not focus on the description of the related fracture network to which each stage of mineralization is linked. However, the understanding of the fracture network at different scales is essential to unravel the uranium-bearing fluid plumbing system and uranium trapping in this type of economic deposit, and also in order to help future exploration. The insertion of the uranium-related fracture system in the whole tectonic history of a region is another critical key to define the fertile tectonic episodes and for establishing the right metalotects. In fact, the lack of detailed structural studies in unconformity-related uranium deposits is overall due to the strong clay alteration associated with this type of deposits (Percival et al., 1993; Beaufort et al., 2005; Jefferson et al., 2007). The lack of oriented micro- and meso-structural data and the difficulty to visualize in 3D complex structures that show significant and rapid lateral and vertical changes between available drill holes constitute additional difficulties (Childs et al., 1996; 2009; Van der Zee et al., 2008; Lunn et al., 2008).

The Kiggavik uranium project is located $80 \mathrm{~km}$ west of Baker Lake, on the eastern border of the Paleoproterozoic Thelon Basin in the Nunavut territory, northern Canada (Fig. 1). It is currently being explored by AREVA Resources Canada (ARC) as a prospective area for uranium due to the similarities in the geological context between the Thelon and the Athabasca basins (Miller and LeCheminant, 1985, Fuchs et al., 1986, Weyer et al., 1987, Fredrich et al., 1989, Fuchs and Hilger, 1989; Jefferson et al., 2007). Uranium deposits in the Kiggavik area (Fig. 2) have recently been interpreted to have some characteristics of unconformity-related deposits (Kiggavik Main and Central Zone deposits: Farkas, 1984; Shabaga et al., 2017b; Bong deposit: Riegler et al., 2016; Sharpe et al., 2015; Quirt, 2017; End deposit: Chi et al., 2017; see also Fayek et al., 2017). In contrast to the Athabasca Basin, where ductile deformation involving graphitic and mineralized shear zones are commonly observed, the tectonic style of deformation and mineralization in the Kiggavik area is dominantly brittle, as exemplified by the presence of cataclastic to ultracataclastic fault rocks and mineralized veins. Ductile to ductile-brittle shear zones are rarely observed and their reactivation appears not to be a key process controlling 
uranium mineralization there (Johnstone et al., 2017). Previous studies of the various deposits in the Kiggavik area focused on the characterization of mineralizing fluids and their alteration products, through geochemical and isotopic analyses of uranium oxides and clay minerals (Farkas, 1984; Riegler et al., 2016a; Shabaga et al., 2015; Sharpe et al., 2015; Potter et al., 2015; Chi et al., 2017; Fayek et al., 2017; Quirt, 2017; Shabaga et al., 2017a, 2017b). While the knowledge in these various fields has greatly improved in the last years, the tectonic history, the structural controls, and the relative timing of the deposits in the Kiggavik area remain poorly understood. Discovered in 2014, the Contact prospect is the latest discovery in the district and was found using a multidisciplinary approach combining GIS-based mineral prospectivity analysis of the available airborne and ground geophysical data (Robbins et al., 2015; Roy et al., 2017).

The aims of this paper are: (i) to accurately reconstruct the tectonic events and sequence of fracturing (mineralized and non-mineralized) in the Contact prospect, (ii) to decipher the spatial organization of the resulting fracture sets in order to unravel the structural controls and relative timing of uranium mineralization in the Contact prospect, and (iii) and in a more general perspective, to provide better constraints on classic models of mineralized fracture networks for unconformity-related uranium deposits. The identification and characterization of fractures along with the reconstruction of the relative chronology on the basis of observed crosscutting relationships and widespread oriented data allows for accurately determining the structural control of the uranium mineralization and alteration at the Contact prospect for the first time in the Kiggavik area.

\section{Geological setting of the Kiggavik area}

\subsection{Regional setting}

The Thelon (ca. 1670-1540 Ma, Hiatt et al., 2003; Davis et al., 2011) and Athabasca (1740_ $1540 \mathrm{Ma}$, Ramaekers et al., 2007) basins are Proterozoic intracratonic basins (Gall et al., 1992) hosted by the Churchill-Wyoming craton, which resulted from the Paleoproterozoic collisional amalgamation of the Rae domain to the northwest with the Hearne domain to the SE (Hoffman, 1988; Fig. 1). These basins are located between the eroded remnants of the Trans-Hudson orogenic belt to the SE (ca. 2070-1800 Ma, overall NW-SE shortening) and the Thelon-Taltson orogenic belt to the west (ca. 2020-1900 Ma, overall E-W shortening). At the regional scale, the main structural feature within the Churchill-Wyoming craton is the Snowbird Tectonic Zone (STZ in Fig. 1), a tectonic trend which has given rise to many interpretations (see for example 
Hoffman, 1988, Hanmer et al., 1995; Ross et al., 2000; Berman et al., 2007). Recent field observations by Regan et al. (2014) on the Cora Lake Shear Zone lead them to propose an intracontinental crustal-scale structure formed at ca. $2600 \mathrm{Ma}$, which underwent several later episodes of transpressional reactivation, with sinistral and dextral motions in response to the Thelon and Trans-Hudsonian orogenies from 1900 to 1820 Ma (Sanborn-Barrie et al., 2001; Mills et al., 2007; Regan et al., 2014). Aeromagnetic maps show that a major fault trend in the Kiggavik area, the Andrew Lake Fault (ALF) connects to the STZ (Fig.1).

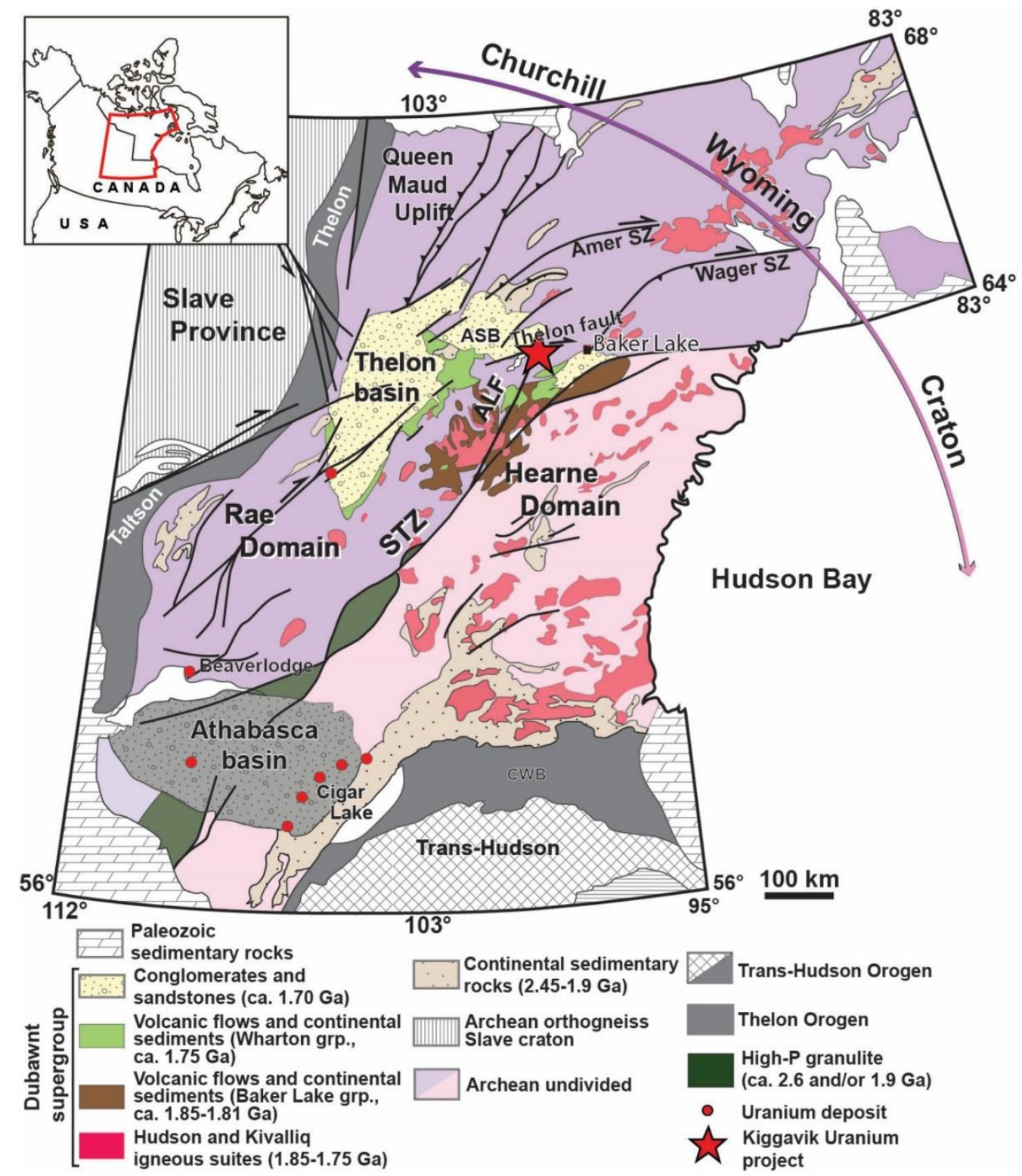

Figure 1: Geological map of the Churchill-Wyoming craton showing the location of the Athabasca and Thelon basins. The Kiggavik area is located between the Thelon fault and the Snowbird Tectonic Zone (STZ). CWB: Chipewayan-Wathaman batholith, ALF: Andrew Lake Fault, ASB: Aberdeen sub-basin. (modified after Eriksson et al., 2001; Peterson et al., 2002). 
The Thelon Basin consists of the Thelon Formation, an 1800 meter-thick sedimentary pile of conglomerates and coarse-grained sandstones, overlain by ca. 1540 Ma shoshonitic basalts of the Kuungmi Formation (Chamberlain et al., 2010) and Lookout Point Formation marine dolomites (Gall et al., 1992) of the Barrensland Group (Fig. 2). The Thelon Formation overlies a complex setup of sedimentary and bi-modal volcanic-sedimentary rocks of the Wharton and Baker Lake groups (Rainbird and Hadlari, 2000; Rainbird et al., 2003; Hadlari and Rainbird, 2011), which filled up the Baker Lake Basin that developed between $1850 \mathrm{Ma}$ and $1750 \mathrm{Ma}$ (Rainbird et al., 2006; Rainbird and Davis, 2007). Development of the Baker Lake Basin occurred due to extensional to transtensional rifting tectonics in response to the Thelon-Taltson and Trans-Hudsonian orogenies and was followed by uplifting, extensive erosional planation, and regolith formation linked to thermal subsidence (Rainbird et al., 2003; Rainbird and Davis, 2007; Hadlari and Rainbird, 2011). The Barrensland, Wharton, and Baker Lake groups are parts of the Dubawnt Supergroup (Peterson et al., 2006) (Fig. 2). Major ENE-trending dextral strikeand oblique-slip faults, including the Thelon-Fault (Fig. 1) became active at that time. The Dubawnt Supergroup unconformably overlies the metamorphosed basement consisting of Archean basement rocks that include Mesoarchean (ca. $2870 \mathrm{Ma}$ ) granitic gneisses, 2730-2680 Ma supracrustal rocks of the Woodburn Lake Group (Pehrsson et al., 2013), and a distinctive package of 2620-2580 Ma felsic volcanic and related hypabyssal rocks known as the Snow Island suite (Jefferson et al., 2011a, 2011b; McEwan, 2012; Tschirhart et al., 2013, 2017; Peterson et al., 2015a; Johnstone et al., 2016). These rocks, together with overlying Paleoproterozoic (2300-2150 Ma) rocks of the Ketyet River Group (Rainbird et al., 2010), include a prominent unit of orthoquartzite (Zaleski et al., 2000). The Archean to Paleoproterozoic rocks where intruded by felsic to mafic rocks of the late syn-orogenic TransHudsonian suite and ca. $1750 \mathrm{Ma}$ rapakivi-style Nueltin granite of the anorogenic Kivalliq igneous suite (Hoffman 1988; van Breemen et al., 2005; Peterson et al., 2015b; c.f., Scott et al., 2015). The age of the Thelon Formation is thus bracketed by the age of emplacement of the Nueltin granite suite, ca. $1750 \mathrm{Ma}$, the diagenetic fluoro-apatite in the basal Thelon Formation, ca. $1670 \mathrm{Ma}$ (Davis et al., 2011), and by the alkali basaltic volcanism of the Kuungmi Formation at 1540 Ma that caps the Thelon Formation (Chamberlain et al., 2010).

The diabase dikes of the Mackenzie diabase swarm that form prominent linear aeromagnetic features trending NNW-SSE (Tschirhart et al., 2013; 2017), cut across all of the previous rocks. This intrusive event is dated at 1267 \pm 2 Ma (Lecheminant and Heaman, 1989; Heaman and Lecheminant, 1993), and represents the last magmatic-tectonic event in the region. 


\subsection{Lithostratigraphy and structural trends in the Kiggavik area}

Uranium mineralization in the Kiggavik area are hosted within the Archean and Paleoproterozoic basement rocks marginal to the Aberdeen sub-basin of the Thelon Basin (Jefferson et al., 2011a, b; Fig. 1). The Archean rocks include the Mesoarchean (ca. $2870 \mathrm{Ma}$, Davis et al., 2006) granitic gneisses, the 2730-2680 Ma (Pehrsson et al., 2010) supracrustal rocks of the Woodburn Lake Group and the distinctive package of 2620-2580 Ma (Rainbird et al., 2010) felsic volcanic and related hypabyssal rocks of the Snow Island suite (metarhyolites, epiclastics, and tuffs in Fig. 3). These rocks are overlain by the Paleoproterozoic (2300-2150 Ma, Rainbird et al., 2010) orthoquartzite of the Ketyet River Group (Fig. 3). These various groups are intruded in the area by the Schultz Lake Intrusive Complex (SLIC) (Scott et al., 2015).

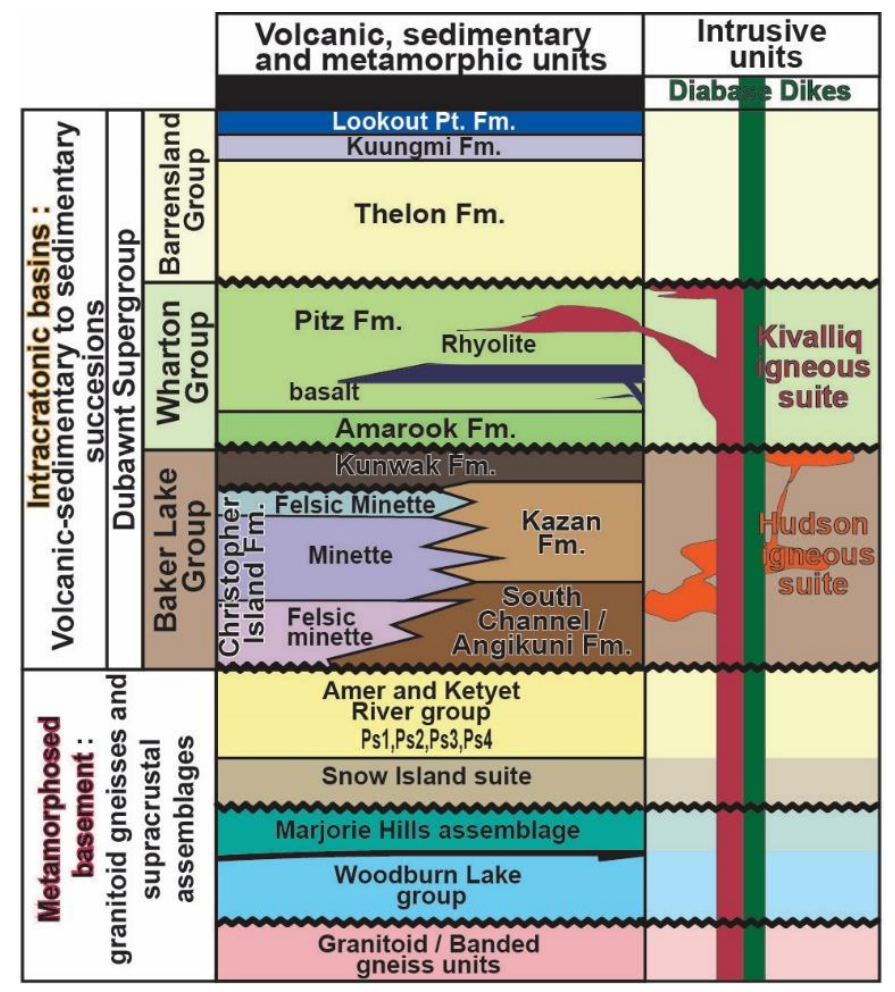

Figure 2: Simplified stratigraphic column of lithological and intrusive units in the Western Churchill Province (modified after Peterson et al., 2015).

The SLIC comprises two groups of rocks with contrasting origins, but with some overlap in geochemical and petrographic features (Scott et al., 2015): (i) the "Hudson granite" consists in non-foliated granitoid sills, syenites, and lamprophyre dikes of the late syn-orogenic TransHudsonian suite. The Hudson granite represents the first pulse of magmatic activity at 1845$1795 \mathrm{Ma}$ in the Kiggavik area (peak around $1825 \mathrm{Ma}$, Van Breemen et al., 2005). (ii) The 
"Nueltin granite" consists in anorogenic granite to rhyolite of the Kivalliq igneous suite (1770$1730 \mathrm{Ma}$, Peterson et al., 2015a), including the McRae Lake dikes and minor Dubawnt minette intrusives of the Dubawnt Supergroup (Scott et al., 2015). The Nueltin granite represents a second pulse of magmatic activity in the area dated at $1750 \mathrm{Ma}$.

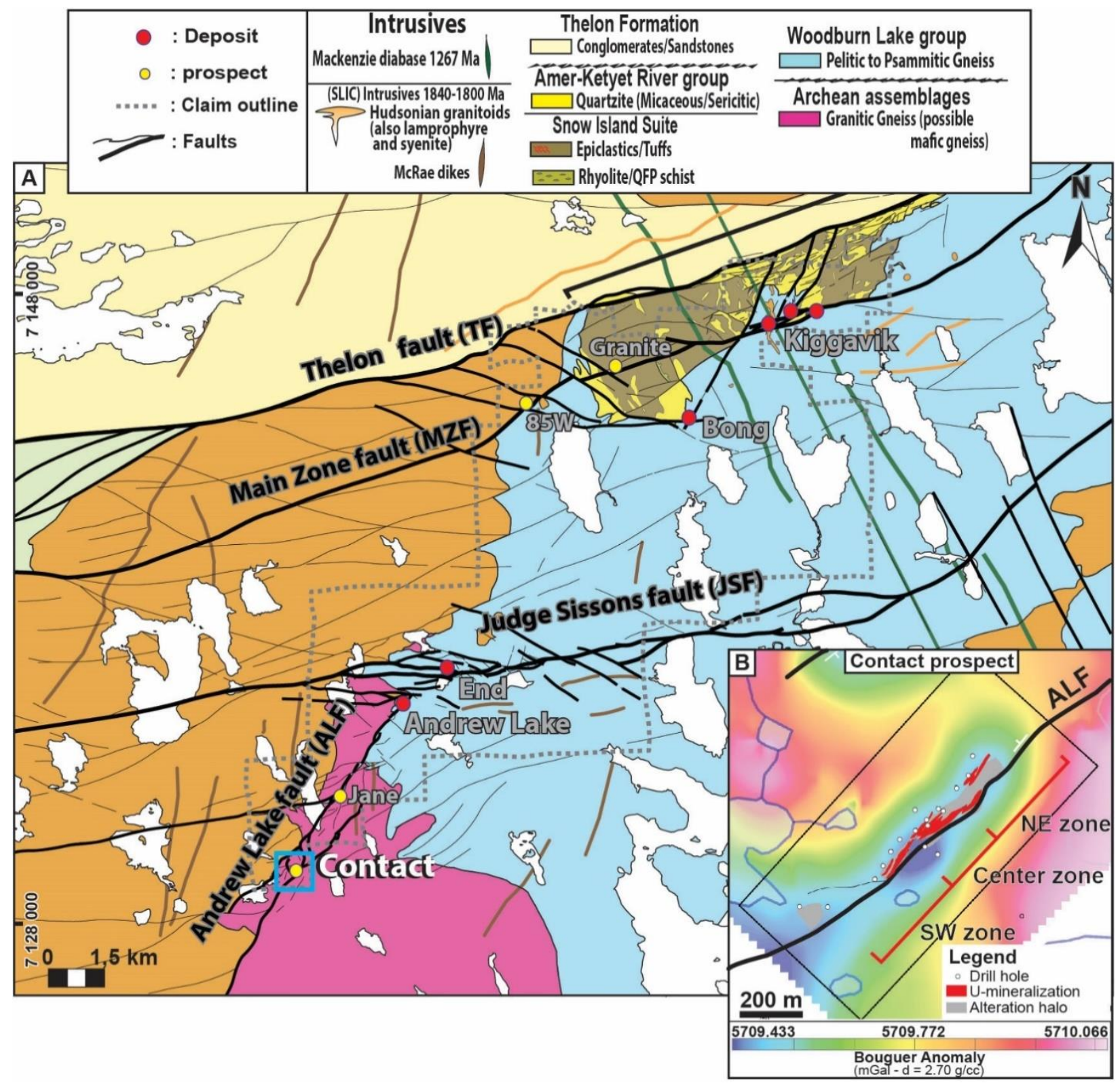

Figure 3: A) Simplified geology map of the Kiggavik area (AREVA internal document). Deposits and prospects are indicated with circles. The Contact prospect is located in the southwest, on the Andrew Lake Fault. The blue square locates B. B) Footprint of the mineralization ( $>0.0425 \% \mathrm{U}_{3} \mathrm{O}_{8}$, in red) and the alteration halo (in grey) projected on the Bouguer anomaly map of the Contact prospect distributed into three mineralized zones (NE, Center and SW 
zones) (from Roy et al., 2017). The black trend represents the trace of the ALF at the depth of the mineralization.

All the previously described rock units are unconformably overlain by the Thelon Formation, which crops out in the northern part of the Kiggavik property (Fig. 3). The diabase dikes of the Mackenzie diabase swarm cut across all of the previous rocks in the Kiggavik area.

The main structural features in the Kiggavik area are the ENE-trending Thelon fault (TF) and Main Zone fault (MZF) in the north of the permit, the ENE-trending Judge Sisson fault (JSF) in the central part, and the NE-trending ALF in the southwestern part (Fig. 3). The MZF hosts the 85W and Granite prospects and the Kiggavik (Main, Central, and East Zones) deposits. The End deposit is hosted by the JSF, while the Andrew Lake deposit and the Jane and Contact prospects occur along the ALF (Fig. 3). Tectonic initiation of these faults goes back to the accretion of cratonic blocks during the Trans-Hudsonian orogeny. The TF constitutes the boundary between the siliciclastic sedimentary rocks of the Thelon Formation to the north and the metamorphosed basement rocks to the south (Fig. 3). The TF offsets the SLIC Hudson granite of at least $25 \mathrm{~km}$ with a right-lateral component (Tschirhart et al., 2013) and its northern hanging-wall is down-thrown by up to $700 \mathrm{~m}$ (Davis et al., 2011). South of the TF, magnetic maps show that the SLIC is crosscut by numerous ENE-trending parallel and sub-parallel faults with apparent right-lateral displacement. The second ENE-trending major fault is the JSF (Fig. 3). The JSF dips steeply to the north on discontinuous outcrops and in drill holes. The NEtrending ALF constitutes the mapped boundary between the Hudson granite to the west and the metamorphosed basement rocks to the east (Fig. 3). The ALF is delineated from interpretation of aeromagnetic and ground gravity maps (Tschirhart et al., 2017; Roy et al. 2017), as outcrops are almost non-existent. Its trend is reported on Figure 3. A main feature of both the JSF and the ALF, which is observable on outcrops and systematically intersected by drill holes, is an extensive silicification characterized by a quartz-healed breccia, named in the literature as the Quartz Breccia (QB) and described in detail hereafter.

\section{Sampling and methodology}

Eighteen inclined -mostly to the SE-drill holes from two exploration campaigns in 2014 and 2015 were examined in this study. The drill holes targeted gravimetric anomalies related to ore and rock alteration (Roy et al., 2017). More than $4000 \mathrm{~m}$ of drillcores have been logged in order to identify mineralizations, lithologies, faults, and fractures. Fault zones were characterized by 
identifying the core of the fault (fault core) through the presence of fault rocks, such as breccias or gouges whereas fault damage zones (Chester and Logan, 1986; Wibberley et al., 2008; Faulkner et al., 2010) were documented by associated veins (mode I or mixed mode I-mode II), joints (mode I) and undifferentiated fractures; "undifferentiated fracture" in this case relates to a fracture plane which cannot be unambiguously classified as vein, joint or fault/micro-fault (no evidence of kinematics) at the time of observation. Fracture corridors and isolated veins, joints and fractures were also systematically reported. Drillcore was oriented using a Reflex ACT III digital core orientation tool (Bright et al., 2014), and then a protractor was used to measure angles between fractures and the core axis (alpha angle). The angle between the bottom of the hole and the inflection line (beta angle) was also measured for calculation of true dip/dip direction data. Acoustic televiewer probing ABI40 (Williams et al., 2004) was run through key holes providing accurate oriented data in faulted core intervals. The data were processed to their true orientation and plotted with Dips 6.0 software by Rocscience. Uncertainty on orientation measurements is usually about $10^{\circ}$ as estimated from the comparison between oriented core-measurements and acoustic televiewer data. Kinematic indicators are rare. Some were identified and measured occasionally, but the amount of collected data appeared to be statistically insufficient to insure proper interpretation. The acquisition of oriented data from exploration drillcores can be limited because the more the rock fractured and altered (i.e. fault damage zone or fault core) the lower the probability of getting drillcore suitable for orientation. Recent drilling in the Kiggavik area was done with NQ $4.5 \mathrm{~cm}$ of diameter double tubing. The holes drilled in the Contact prospect provided enough good quality oriented core to collect reasonable statistically representative data of the various fault and fracture sets. Oriented data was also supported by local acoustic televiewer probe.

Ninety-six core samples were collected (10 and $20 \mathrm{~cm}$ in length) from fractured zones; fortynine of which were mineralized. All samples were studied from the macro- to the micro-scale in order to define fracture cross-cutting relationships, mineral paragenesis, and alteration. Sixtyfour thin sections were prepared for petrographic and microstructural studies.

Optical microscopy (plane polarized transmitted and reflected light microscope Motic BA310 POL Trinocular, equipped with a $5 \mathrm{M}$ pixel Moticam camera), Scanning Electron Microscopy (SEM) JEOL J7600F field-effect coupled with a X-Ray Microanalysis device (EDAX Genesis) and cathodoluminescence (CITL Cold Cathodoluminescence device Model MK5-1) were systematically used for accurate definition of fracture-cementing/coating phases and mineral paragenesis. Clay mineral species and uranium oxides $\left(\mathrm{UO}_{2}\right)$ were characterized with an electronic microprobe (CAMECA SX-100) and by SEM performed at the "Service Commun de 
Microscopie Electronique et de Microanalyses (SCMEM)" at the University of Nancy-CREGU, in France. The CAMECA SX-100 was operated at up to $30 \mathrm{kV}$ for elements with high atomic numbers. The calibration used natural and synthetic oxides and/or alloys (orthoclase, albite, $\mathrm{LaPO}_{4}, \mathrm{CePO}_{4}$, wollastonite, $\mathrm{UO}_{2}, \mathrm{PbCrO}_{4}$, olivine, $\mathrm{DyRu}_{2}$ ). The analytical conditions at SCMEM were 10-nA current, accelerating voltage of $15 \mathrm{kV}$, counting time of $10 \mathrm{~s}(\mathrm{~K}, \mathrm{Na}, \mathrm{Ca}), 20 \mathrm{~s}$ (Ce, $\mathrm{U}, \mathrm{Si}$ ), 40s (Dy), 50s for $\mathrm{Pb}$, and 60s for $\mathrm{La}$. The SEM was operated at low accelerating voltage $(10 \mathrm{kV}), 100 \mathrm{nA}$ filament current, and $600 \AA$ beam width for a working distance between 8 and $39 \mathrm{~mm}$. The cathodoluminescence microscopy was operated between 10 and $12 \mathrm{kV}$ gun potential and between 150 and $350 \mu \mathrm{A}$ beam current. Observations were performed at the "Departament de Mineralogia, Petrologia i Geologia Aplicada, Facultat de Ciències de la Terra", at the University of Barcelona, in Spain.

\section{Fracturing stages and mineral paragenesis}

The Contact prospect is located along the ALF, one kilometer east of the Hudson granite (Fig. 3A). Uranium mineralization is hosted in faults, veins, and other fractures (described in detail hereafter) that occur in moderately foliated, granitic to granodioritic gneiss of inferred Archean age. Granitic sills and dikes, syenites to granites, and lamprophyre dikes of the SLIC are common and are locally mineralized. Interpretation of the newly acquired ground magnetic and gravity data suggests that the ALF is divided in two overlapping fault segments between the Jane and Contact prospects (Fig. 3A) (see also Roy et al., 2017). The southern fault segment dips to the NW and hosts the Contact prospect, while the northern fault segment dips to the SE and hosts further north the Jane prospect and the Andrew Lake deposit (Fig. 3A). As presented by Roy et al. (2017), the mineralization in the Contact prospect is distributed in three pods called SW, Center, and NE zones (Fig. 3B).

The microstructural and petrographic study combining optical, cathodoluminescence microscopy, and SEM observations has allowed for the recognition of ten main fracturing stages. We define "fracturing stage" as the fracture set or group of fracture sets that are associated with the same paragenesis indicating the same step or period of fluid/fracture/rock interaction. A fracture stage can correspond to a well identified and unique tectonic episode, or to one or several episodes of fracture reactivation and mineralization. The various recognized fracture stages in the Contact prospect are presented below by their chronological order based on observed cross-cutting relationships. Three fracture stages are associated with uranium mineralization, of which two are primary mineralizing stages, and one is a remobilizing stage. 
The other seven fracture stages are barren and can be indirectly associated with the ore deposit either by having enhanced the permeability of the host rock by micro-fracturing or by having controlled fluids that have reworked uranium mineralizations in late stage.

\subsection{Fracturing stage 1: First tectonic activity observed on the Andrew Lake Fault}

The first fracturing stage (f1) is represented by the occurrence of cataclastic to ultracataclastic faults observed locally in some drill holes (Fig. 4A-B). Fault zones exhibit cataclasites and breccias of small clasts with weak illitic alteration, cemented with illite and finely crushed grains from the host rock; they are usually pervasively silicified and crosscut by quartz veins (Fig. 4B).

Granitic gneiss and various intrusive rocks (granite, fig. 4A, lamprophyre, syenite) are crosscut by these fault zones and form the breccia clasts. This stage of faulting is the earliest brittle tectonic deformation stage recognized on the ALF. No evidence of ductile or ductile-brittle shearing was observed within the ALF at the Contact prospect. Related faults were observed only in the vicinity and/or within the quartz breccia of the following deformation stage that subsequently silicified and crosscut these faults (Fig. 4C to D). The strong overprinting by quartz veins and quartz breccias prevented the collection of statistically significant oriented data, and "screened" the full recognition of these faults. This fracturing stage is the oldest recognized at the Contact prospect (fig.4 E).

\subsection{Fracturing stage 2: quartz breccia (QB) and first stage of oxidation}

One of the most remarkable deformation features of the JSF and ALF in the Kiggavik area is the so-called hematitic quartz-rich breccia, first described in the area by Cogema's field geologists in 1994 from outcrops along the JSF (Fig. 5A). This breccia is also called barren quartz breccia by Chi et al. (2017) in their fluid inclusion study at the End deposit and called hereafter the quartz breccia (QB). The QB consists of mosaic quartz-sealed breccia and veins (Fig. 5A-B), and reflects a major regional silicification event (Turner et al., 2001; Hadlari and Rainbird, 2011). Lithologies within and around the $Q B$ display a pervasive, red-purple hematization (Fig. 5B and C). This hematization is the first hematization event identified in the Contact prospect and Kiggavik area. 


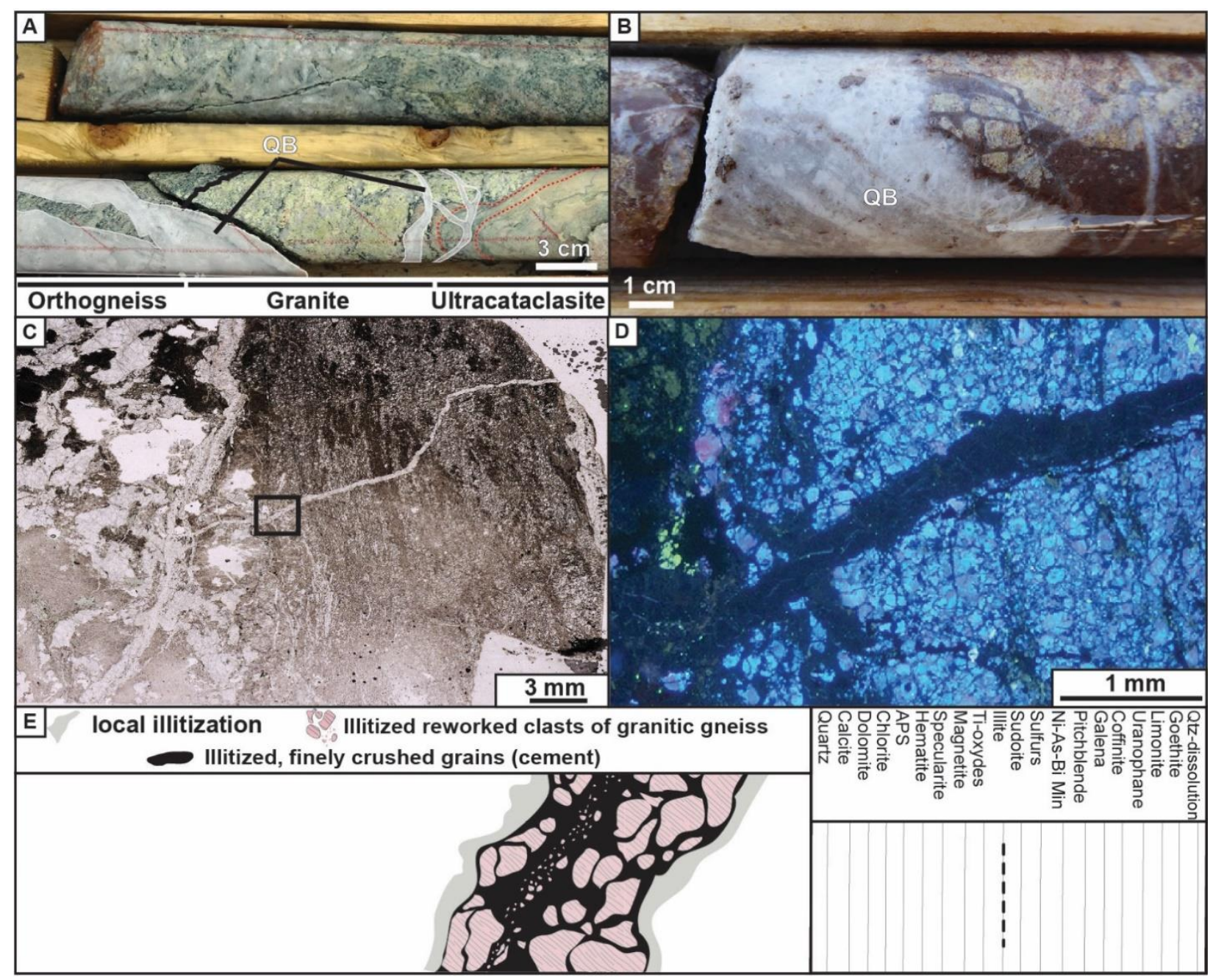

Figure 4: Fracturing stage f1: A) Drillcore box photograph showing an ultracataclastic fault rock in a granite that intrudes a granitic gneiss. Both lithologies are then crosscut by quartz veins from fracturing stage 2. B) Drillcore photograph of a silicified and illitized cataclastic fault rock crosscut by white quartz and grey quartz veins of the second fracturing stage. C) Optical microscopy transmitted light photograph of an ultracataclastic fault rock crosscut by a thin quartz vein of the second fracturing stage. The black square locates picture $D$. D) Cathodoluminescence microscopy photograph. Zoom in showing the crosscutting relationship between the ultracataclastic fault rock and the quartz vein (dark blue weak luminescence). E) Sketch depicting the textural features with the paragenesis characterizing this fracturing stage.

At the Contact prospect, the QB was intersected by most of the drill holes at the bottom of all mineralized pods discovered to date. The breccia zone displays abundant, pervasively hematized hetero-lithic clasts of various intrusive rocks such as lamprophyre, granite, or syenite and granitic gneiss, and a quartz-healed silicified matrix. The QB can be divided into damage 
zones characterized by numerous quartz veins $(<5 \mathrm{~cm}$ thick), and core zones characterized by dominant massive quartz sealed breccias ( $>50 \mathrm{~cm}$ thick) over minor quartz veins. The QB crosscuts and postdates the fault of the first brittle tectonic event (f1), the associated fractures of which were re-activated as pathways for the silica-rich fluids. A similar chronology has been recognized at the Andrew Lake (Shabaga et al., 2017a) and End deposits.

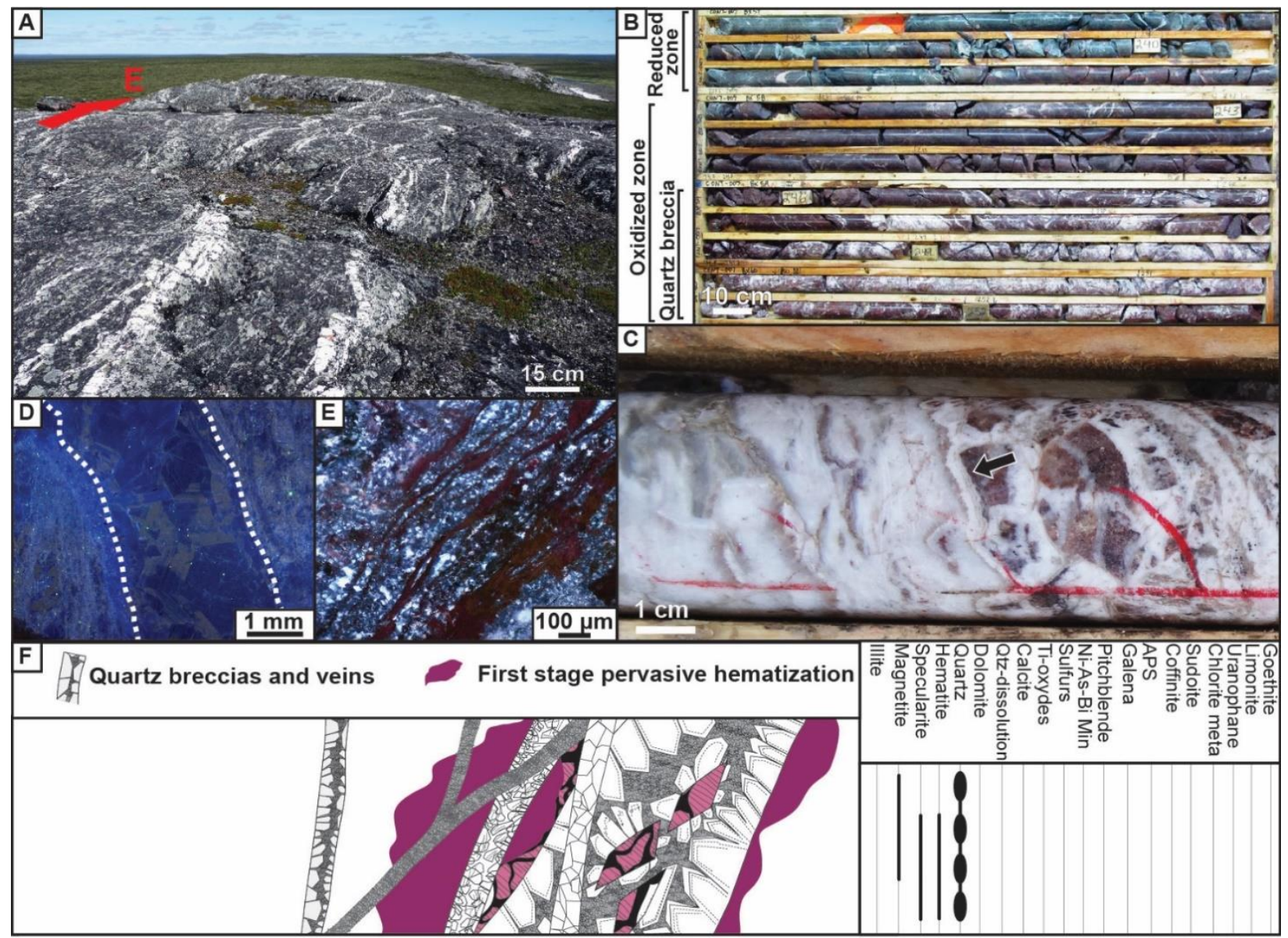

Figure 5: Fracturing stage f2 (QB): A) Outcrop view looking east on the N80-trending steeply dipping to the north JSF underlain by at least 10 meters of white quartz veins. B) Core box photograph showing examples of the quartz breccia and associated deep red to purple red pervasive hematization (Contact prospect). C) Massive white quartz breccia with opaque white quartz, grey microcrystalline quartz and angular granitic gneiss clasts. Colloform quartz texture is visible pointed by the arrow (Contact prospect). D) Cathodoluminescence microscopy photograph showing a vein of zoned quartz (white dot line) crosscutting microcrystalline quartz. E) Microscopy reflected light photograph showing alternating micro-crystalline quartz and hematite in a vein. F) Sketch depicting the textural features with the paragenesis characterizing this fracturing stage. 
Numerous generations of quartz veins crosscut each other (Fig. 5D), which makes it difficult to establish a proper chronology between all quartz textures. However, two groups of textures dominate: primary crustiform, comb and zonal growth textures, and secondary microcrystalline mosaic quartz, feathery and ghost sphere growth textures (Bodnar et al., 1985; Dong et al., 1995; Moncada et al., 2012). The most representative quartz texture observed consists of white quartz crystals with alternating growth zones of blue and light brown colors under cathodoluminescence; this is usually observed as a late quartz generation (Fig. 5D). Microcrystalline quartz is observed in different settings: oriented along planes (stylolite-like), following boundaries of quartz veins or present in the center of quartz veins.

The pervasive purple-red hematization of the breccia host rocks (Fig. 5C) is characterized at the micro-scale by disseminated, fine-grained hematite, magnetite and rare specular hematite (also filling vugs). Veins of crustiform hematite and anhedral microcrystalline quartz (Fig. 5E) attest for synchronous brecciation and oxidation phenomena, which is the second fracturing stage observed at the Contact prospect (fig. 5F).

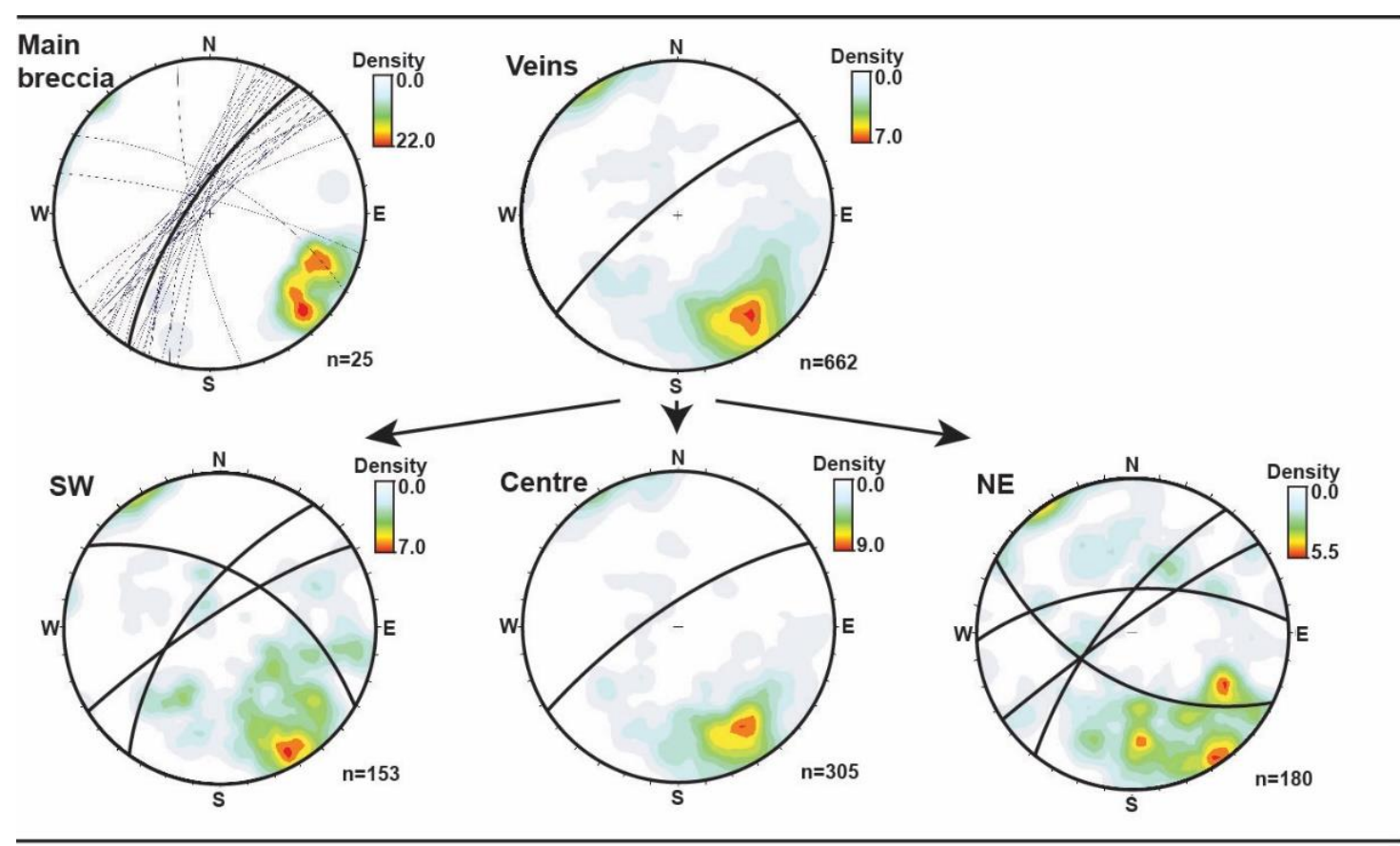

Figure 6: Fracturing stage f2: oriented data of quartz veins and breccia of QB. Bold black greatcircles indicate the main trend. Schmidt's lower hemisphere plots.

Veins of the QB are divided into massive quartz veins measured in the breccia core and minor veins measured in damage zones (Fig. 6). Data are separated by location: Southwest $(\mathrm{SW})$, Center, and Northeast (NE) zones. Oriented data plots show that the massive quartz 
veins are mainly oriented $\mathrm{N} 035^{\circ}$, with a steep dip to the NW. Minor quartz veins strike on average $\mathrm{N} 60^{\circ}$, with a steep dip to the NW. Minor veins are much more focused along one direction in the Center Zone, compared to the SW and NE zones. The QB is also thicker in the Center Zone where it reaches up to $70 \mathrm{~m}$ in drill hole CONT-10, (Fig. 7), with $30 \mathrm{~m}$ of fault core zone and a well-developed damage zone up to $40 \mathrm{~m}$ thick.

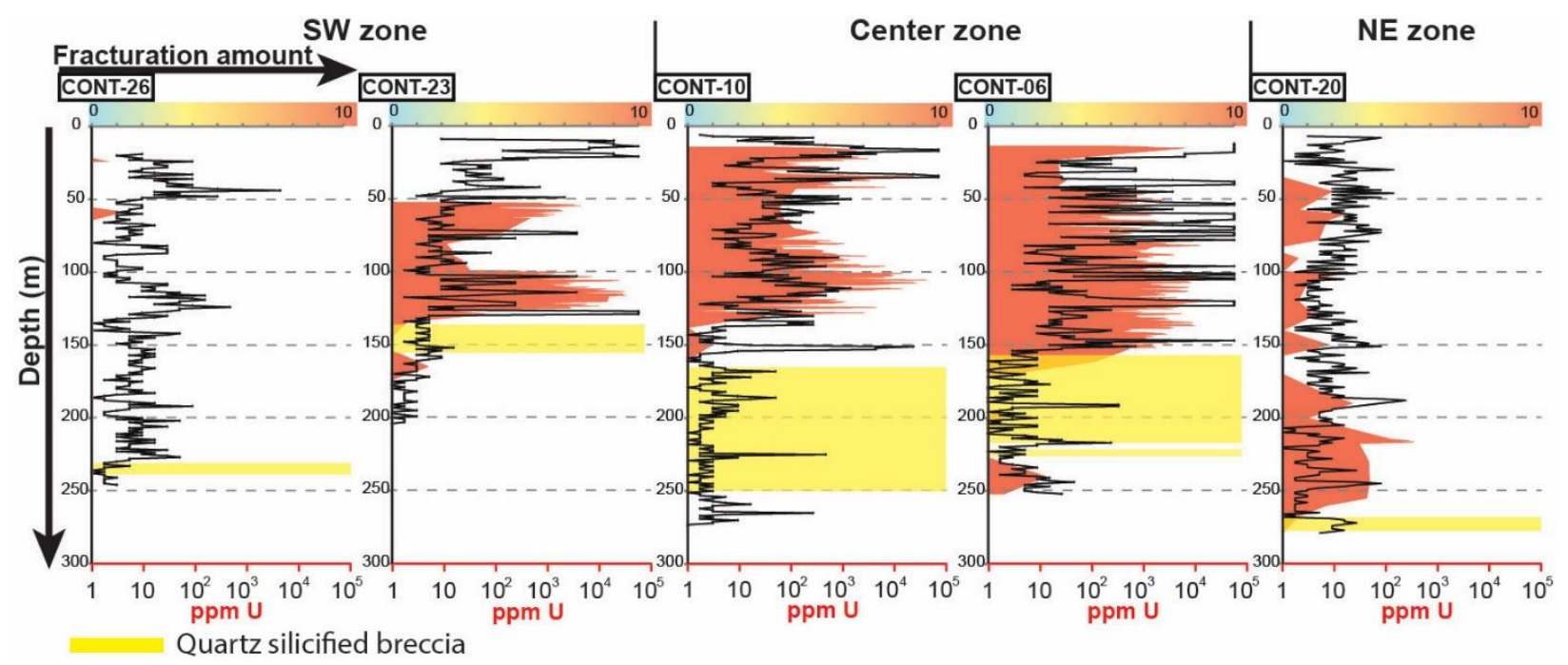

Figure 7: Distribution of fracture density as a function of depth. Fracture density as black lines; 0: non-fractured drill-core, 10: intensely fractured drill-core. Uranium mineralization in red: $U$ in ppm measured by assays, logarithmic scale). The QB is highlighted by a yellow zone including both the core and the damage zone.

\subsection{Fracturing stages 3 and 4: carbonate-filled veins}

The fracturing stage 3 (f3) is characterized by isolated veins filled by dolomite. Dolomite cement fills newly formed veins and vugs in inherited quartz-filled veins (Fig. 8A). In the latter case, quartz crystals display edges with evidence of corrosion and microcrystalline quartz is replaced by dolomite (Fig. $8 \mathrm{~B}$ ). Dolomite crystals are also disseminated within the host rock.

The fracturing stage 4 ( $f 4$ ) consists of isolated calcite-filled veins that crosscut f1 to f3, including the dolomite veins. Calcite occurs as the main vein cement and also as later cement infilling the remnant voids partially filled by dolomite or locally disseminated within the host rock. Calcite also appears as replacing pre-existing sulfide minerals. Calcite veins display two apparent pseudo-conjugate trends: E-W and NW-SE, with conjugate dip directions (Fig. 8C). Observations under cathodoluminescence confirm that dolomite and calcite veins crosscut quartz veins of the QB event (fig. 8D). 


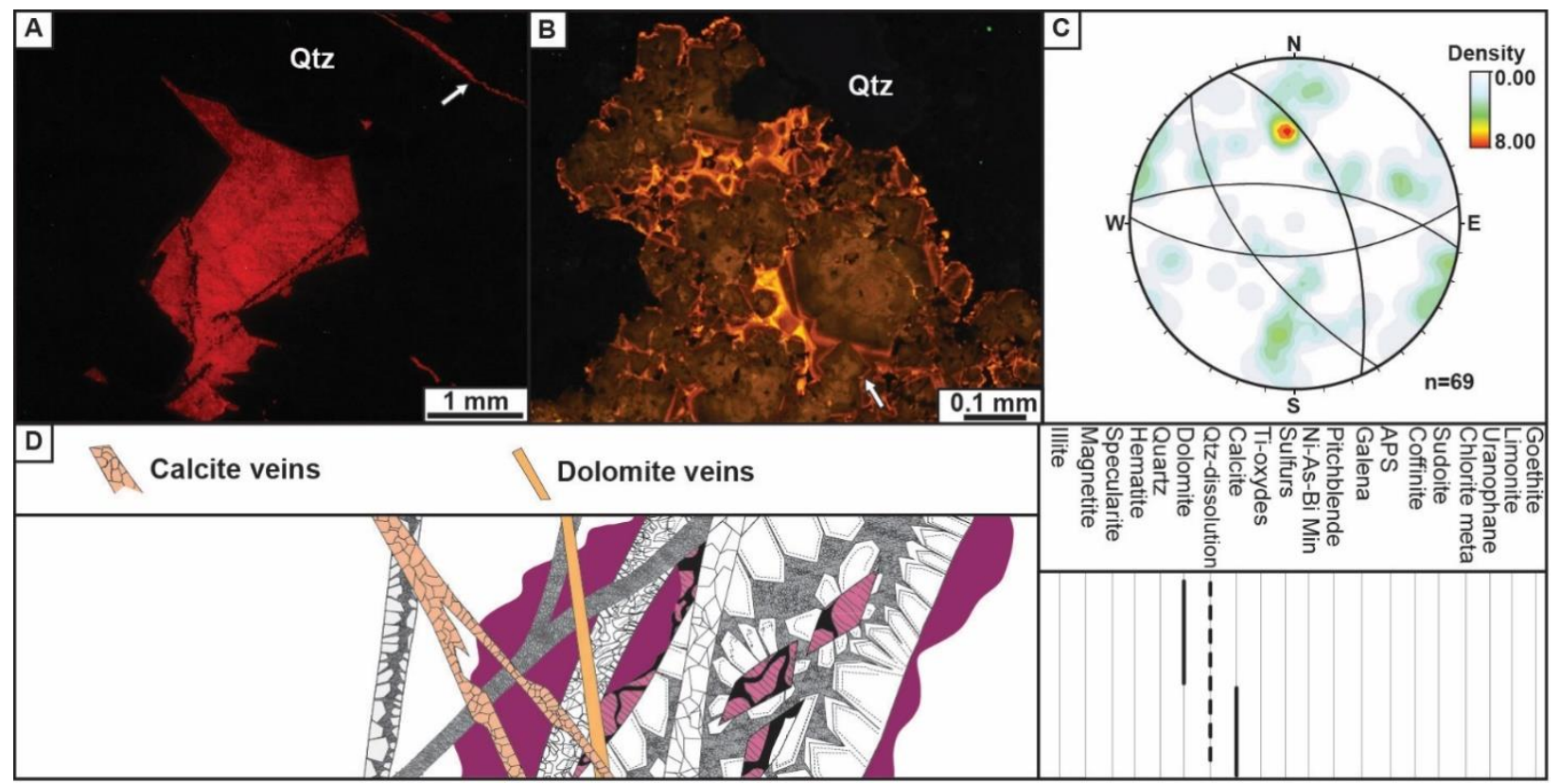

Figure 8: Fracturing stage $\mathrm{f} 3$ and $\mathrm{f} 4: \mathrm{A})$ Cathodoluminescence microscopy photograph showing a vein cemented with dolomite (f3) crosscutting quartz crystals (white arrow, quartz vein of the QB). B) Cathodoluminescence microscopy photograph showing calcite replacing polygonal shaped sulfide mineral phantoms (white arrows). C) Oriented data for calcite filled veins. Schmidt's lower hemisphere plot. D) Sketch depicting the textural features with the paragenesis characterizing this fracturing stage.

\subsection{Fracturing stage 5: uranium-related faults (first stage of uranium mineralization)}

This fracturing stage (f5) is represented by mineralized faults and veins, and embodies the first stage of uranium mineralization in the Contact prospect. The mineralized fractures crosscut all features of stages $\mathrm{f} 1$ to $f 4$, and reactivate and/or cause micro-fracturing of quartz veins of the QB. This initial mineralization with pitchblende and coffinite with other uranium oxides (see hereafter) generated the highest ore grades in the Contact prospect (i.e., $4.76 \% \mathrm{U}_{3} \mathrm{O}_{8}$ over $50 \mathrm{~cm}$ ), although it is not the largest in terms of spatial extent. Uranium mineralization macroscopically appears in two settings that can coexist: i) in newly formed fault zones, coating undifferentiated fractures and veins, locally observed as disseminated within cataclastic fault rocks, and filling fault damage zone-related fractures with other ore minerals (Fig. 9A-B). ii) in re-opened and mineralized quartz veins of the QB (Fig. 9C-F). Both type of mineralized faults and veins are also characterized by iron oxide removal or bleaching with weak grey-greenish clay alteration and illitization (see table 1 for clay composition). 

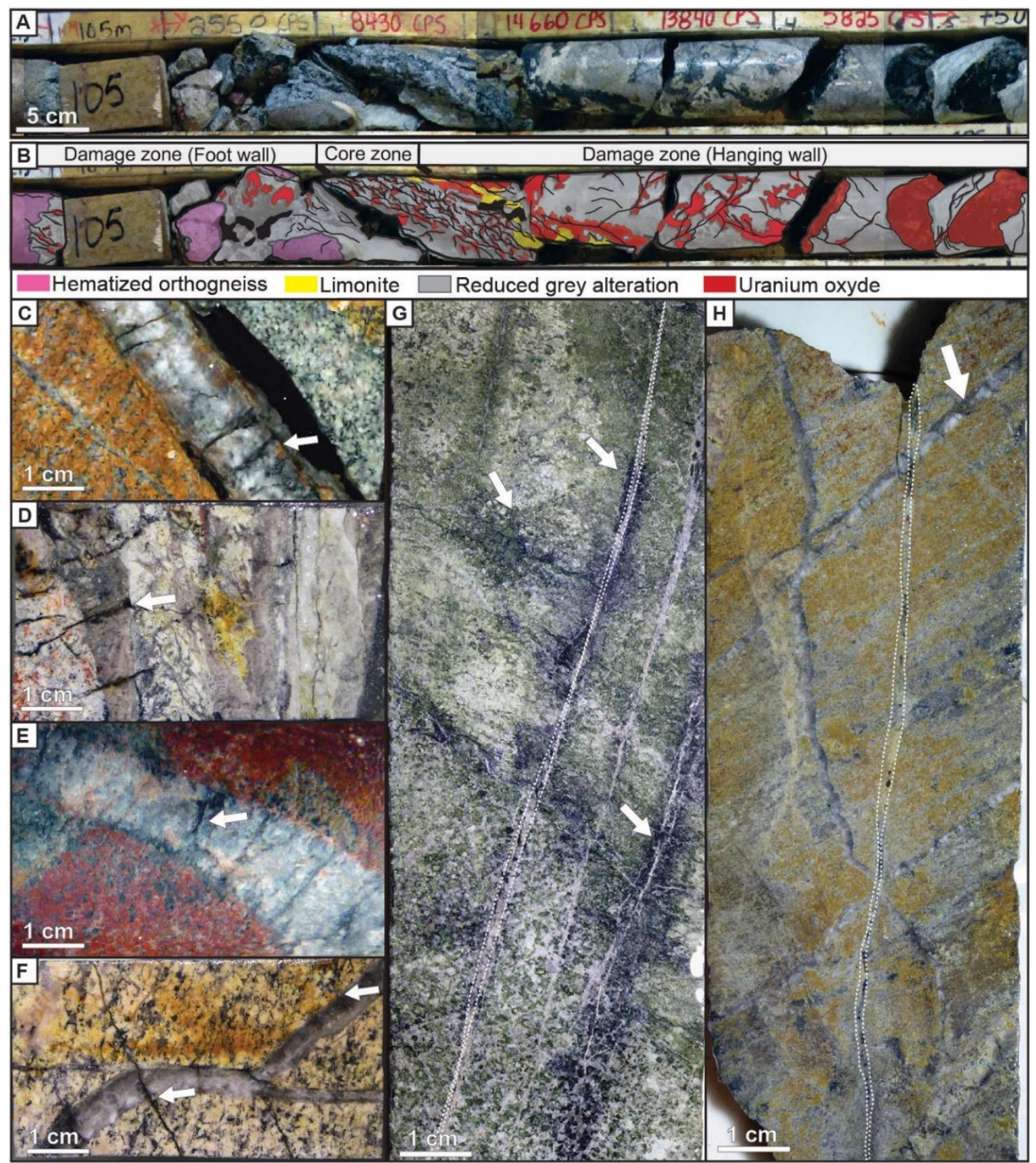

Figure 9: Fracturing stage f5: A-B) Core box photograph and interpretation respectively showing a mineralized cataclastic fault with grey-greenish clay alteration. Mineralization is disseminated within the cataclastic fault core and fills fractures within the fault damage zone. C-F) Core samples exhibiting various examples of quartz veins (QB) with mineralized microveins (pitchblende and sulfide minerals) that orthogonally cut across the vein. G) Core samples displaying mineralized inherited micro-crystalline quartz veins (QB) with haloes of grey-greenish clay alteration. Mineralization (pitchblende) has leaked out into the foliation of the host rock. $H$ ) Core sample with mineralized quartz veins (QB) crosscut by a fracture (white dotted line) cemented with ore minerals. 
Bleaching varies from light (Fig. 9G) to strong (Fig. 9A and H) and correlates to the amount of uranium mineralization. No oxidation of the host rocks has been observed linked to this stage of mineralization. Dolomite and calcite veins from $\mathrm{f} 3$ and $\mathrm{f} 4 \mathrm{can}$ also be locally re-activated and mineralized during this stage.

Quartz veins of the QB contain mineralization along the vein walls and leaking out into the foliation (Fig. 9G and H), or filling micro-veins that orthogonally cut across the veins (Fig. 9C-F). In both occurrences, vein edges show irregular boundaries indicating quartz corrosion or dissolution prior to, or synchronous with, mineralization. The mineralized fractures that orthogonally cut across the quartz veins are a notable macroscopic and microscopic feature of this stage of mineralization, which is still poorly understood. Their geometry varies depending on the texture of the crosscut quartz; microfractures are straight in the case of micro-crystalline quartz, while irregular and along grains boundaries in the case of sub-euhedral quartz (Fig. 10A and B).

Dissolution has also been observed in re-opened and mineralized carbonate veins of the $f 3$ and $\mathrm{f} 4$. In this case, dolomite grains display dissolved boundaries where they are in contact with pitchblende, and calcite is observed as a rim between the pitchblende and dolomite (Fig. 10C). This texture suggests that calcite precipitated coevally with uranium mineralization: calcium was remobilized from the dissolved dolomite into calcite precipitated around the pitchblende or in nearby microfractures. Observations under cathodoluminescence microscopy reveal specific pink-yellowish luminescence along the boundaries of quartz grains and along the boundaries of microfractures in quartz (Fig.10B), cemented with uranium oxides.

\begin{tabular}{lccccccc}
\hline \hline Fracture set & 5 & $6 \mathrm{a}$ & $6 \mathrm{c}$ & $6 \mathrm{c}$ & 7 & 7 & 8 \\
\hline mineral & illite & illite & illite & sudoite & illite & $\begin{array}{c}\text { relict } \\
\text { retromorphic chlorite }\end{array}$ & illite \\
\hline $\mathrm{SiO}_{2}$ (wt. \%) & 53.5 & 47.25 & 48.97 & 33.54 & 46.89 & 37.88 & 51.14 \\
$\mathrm{Al}_{2} \mathrm{O}_{3}$ & 24.64 & 23.1 & 25.55 & 30.17 & 23.69 & 21.2 & 30.71 \\
$\mathrm{~K}_{2} \mathrm{O}$ & 6.97 & 7.05 & 5.65 & 0.48 & 6.79 & 0.28 & 9.97 \\
$\mathrm{CaO}$ & 0.35 & 0.3 & 0.46 & 0.16 & 0.18 & 0.14 & 0.05 \\
$\mathrm{FeO}$ & 2.09 & 4.3 & 0.19 & 1.45 & 5.08 & 19.37 & 1.03 \\
$\mathrm{MgO}$ & 2.58 & 5.76 & 5.35 & 13.9 & 6.17 & 16.07 & 1.9 \\
$\mathrm{MnO}$ & 0.1 & 0 & 0.04 & 0 & 0 & 0.23 & 0 \\
$\mathrm{TiO}_{2}$ & 0.03 & 1.12 & 0 & 0.04 & 0.2 & 0.1 & 0 \\
$\mathrm{Na2O}$ & 0.07 & 0.07 & 0.07 & 0.05 & 0.09 & 0.08 & 0.17 \\
\hline Total & 90.33 & 88.95 & 86.28 & 80.06 & 89.09 & 89.35 & 95.01 \\
\hline \hline
\end{tabular}

Table 1: Representative microprobe analysis of clay species from fracture sets associated with alteration of the host rock. 


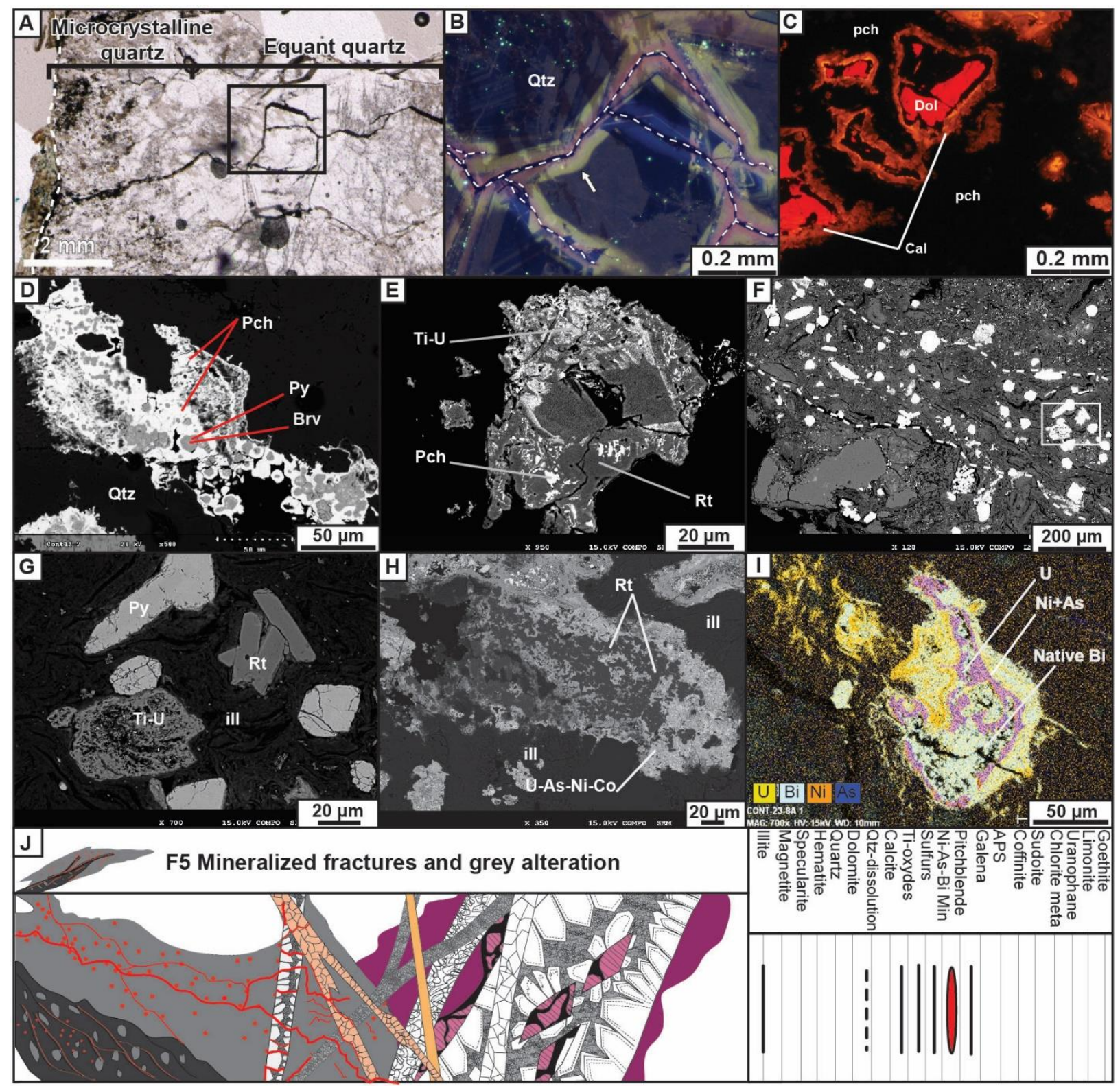

Figure 10: Fracturing stage f5: A) Transmitted light microscopy photograph showing a quartz vein of the QB crosscut orthogonally by mineralized microveins (white dotted line on the left highlights the boundary of the vein). The microvein is filled with pitchblende, pyrite and chalcopyrite. The black square locates photograph B. B) Cathodoluminescence microscopy photograph showing the luminescence irradiation halo surrounding the mineralized microvein traced with the white dot line. C) Cathodoluminescence microscopy photograph showing dissolution of dolomite linked to pitchblende precipitation and carbonate re-precipitation as calcite. D) SEM microphotograph illustrating a microvein crosscutting a quartz vein and cemented with pyrite and bravoite which are coated with anhedral pitchblende. E) SEM microphotograph illustrating rutile with pitchblende micro-inclusions and mixed with uraniferous titanate. F) SEM microphotograph showing a vein (white dot line, from Fig. 10D) cemented with uranium minerals. White square locates photograph 
G. G) SEM microphotograph. Zoom into the core of the previous vein showing: rutile, pyrite, uraniferous titanate and illite. $\mathrm{H}$ ) Subhedral rutile coated with U-As-Ni-Co compounds. I) Anhedral uranium, nickel-arsenide mineral and native bismuth. J) Sketch depicting the textural features with the paragenesis characterizing this fracturing stage.

Uranium minerals at this stage are represented by colloform to xenomorph pitchblende (Fig. 10D) and coffinite, uraniferous titanate, titanium-oxides with pitchblende micro-inclusions (Fig. $10 \mathrm{E}$ ), iron sulfides (mainly pyrite but also chalcopyrite and bravoite, see Fig. 10D and F-G), and illite (Table 1). Rare occurrences of native bismuth and unidentified As-Ni-Co $( \pm U)$ xenomorphic minerals are also associated with xenomorphic pitchblende along microfractures (Fig. $10 \mathrm{H}-\mathrm{I}$ ). Iron sulfides not associated with pitchblende are rare throughout the Contact prospect. The lack of iron sulfides is inferred to be associated to their remobilization (if they were present) due to the pervasive hematization of the QB event along the ALF. This first mineralizing stage which postdates carbonate and quartz veins (fig. 10J) is classified as polymetallic.

Oriented data of the re-openend, orthogonally micro-fractured and mineralized quartz veins show a dominant NE-SW and a minor NW-SE trends (Fig. 11), consistent with the main QB and ALF trends (Fig. 8F), while the newly formed f5 faults and fractures strike nearly perpendicular to the ALF, following the TF trend (Figs. 3, 11).
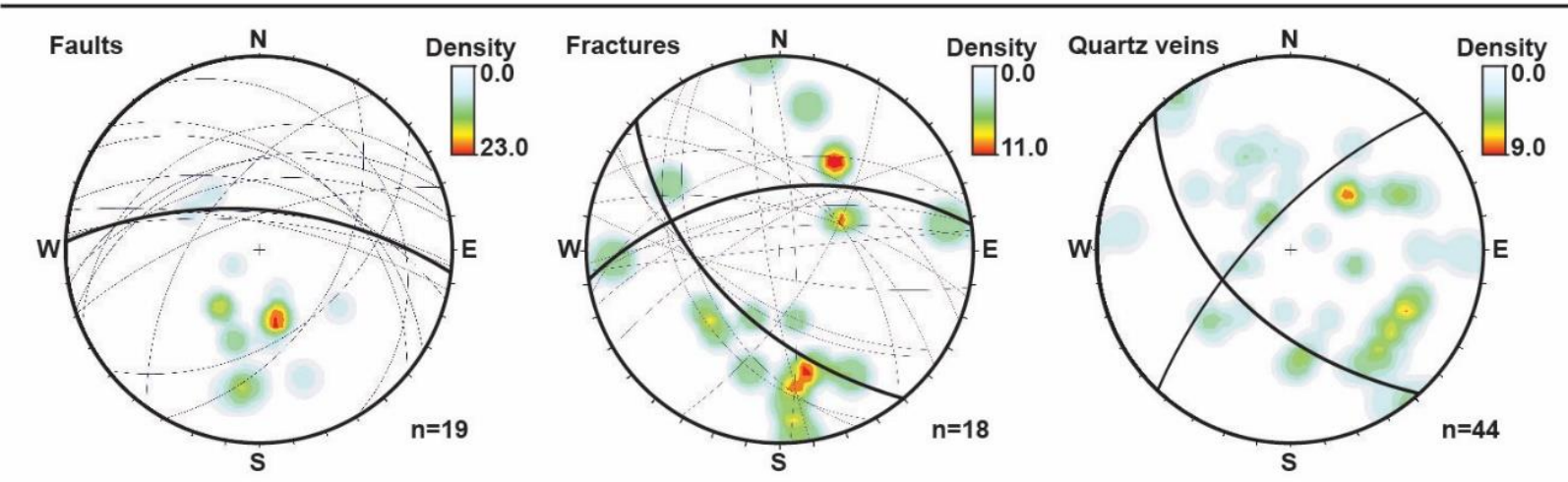

Figure 11: Fracturing stage 5: Oriented data for newly formed mineralized faults, associated fractures (left and middle) and mineralized quartz veins (right). Schmidt's lower hemisphere plot.

4.5. Fracturing stage 6: faulting, second oxidation stage and second stage of uranium mineralization

The fracturing stage 6 ( $f 6 a$ to $\mathrm{f} 6 \mathrm{c}$ ) is the more complex deformation stage. Two sub-stages (f6a and f6c) displaying strong similarities in fault rocks, alteration type, and oriented data were 
distinguished on the basis of crosscutting relationships at the micro-scale and on the presence of uranium mineralization since they are separated by a sub-stage of calcite vein formation (f6b). The spatial association of these calcite veins with the oxidized fault rocks is however difficult to establish precisely because of the small size of the calcite veins $(<3 \mathrm{~mm})$ and the discontinuous picture of the fault zone given by drilling.

\subsubsection{Fracturing stage $6 a(f 6 a)$ : faulting and second stage of oxidation}

Faults that characterize f6a were observed both on outcrops and in drillcores. Fault core rocks contain reworked clasts of the QB (Fig. 12A) and of the Thelon Formation (Fig. 12B). These faults display characteristic oxidized and illitized (Table 1) tectonic breccias and cataclasites (Fig. 12C). Calcite veins are fractured and stained with hematite (Fig. 12D, E) and reworked clasts (Fig. 12F) with remnant minerals like iron sulfide, rutile, and micro-grains of pitchblende of the first mineralization stage are also common (Fig. 12E).

This stage postdates the first stage of uranium mineralization (Fig. 12G). Fine-grained crushed aluminum-phosphate-sulfate (APS) minerals were observed in one sample of hematized ultracataclastic fault rock.

The f6a event is associated with a second oxidation event of the host rock. This oxidation is more closely spatially associated with fault zones and the hematization is less penetrative (centimetre scale) into the host rocks than in the case of the first hematization event linked with the QB (metre scale). It is characterized by fine-grained hematite that imparts the bright reddish color to the fault (Fig. 12E).

Oriented data of f6a (Fig. 13A) needed specific sorting as fracture directions vary with depth and from the Center Zone to the outer zones (SW and NE zones). In the Center Zone, above $170 \mathrm{~m}$, faults orientations are scattered in three different trends (Fig. 13B). 


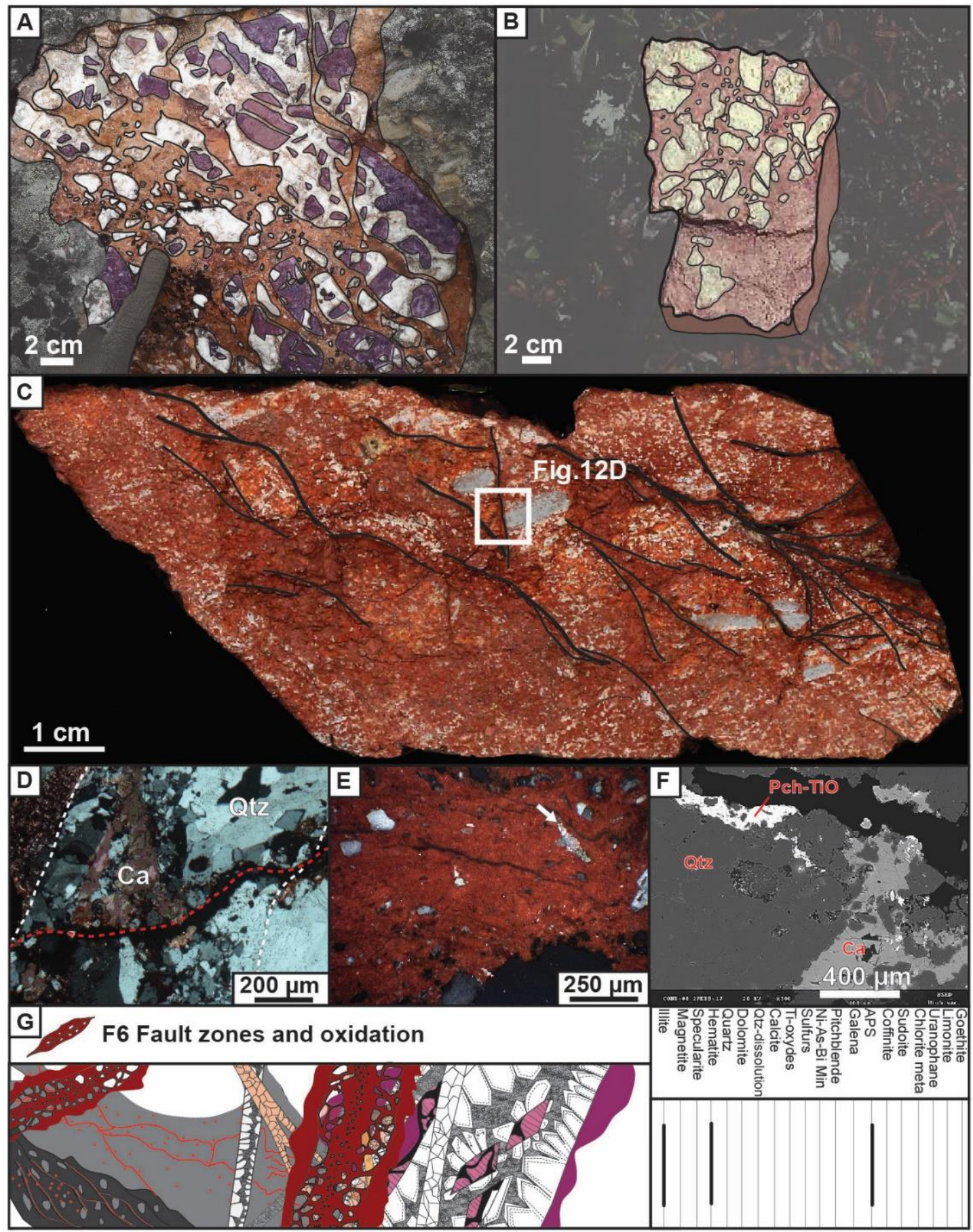

Figure 12: Fracturing stage f6a: A) Tectonic breccia on outcrop in the Kiggavik area embedding heterometric fragments of QB with purple-red hematization (first hematization stage) floating in a matrix consisting of bright red hematized clay (second hematization stage). B) Cataclastic fault rock displaying yellow clasts of the Thelon Formation in bright red hematized clay matrix (second hematization stage). Sample from an outcrop $30 \mathrm{~km}$ west of the Kiggavik area. C) Protocataclastic hematized fault rock. Brecciation of a quartz vein (QB) is visible (white arrow). D) Transmitted light microscopy photograph. Closer view of the hematized fault rock of picture C: brecciated (red dot 
line) quartz vein (white dot line) with vugs filled by calcite (f4). E) Reflected light microscopy photograph showing a hematized ultracataclastic fault rock with microclasts of calcite and quartz. F) SEM photograph. Zoom in a hematized fault rock with reworked quartz vein with calcitecemented fractures hosting remnant xenomorphic pitchblende and rutiles. G) Sketch depicting the textural features with the paragenesis characterizing this fracturing stage.

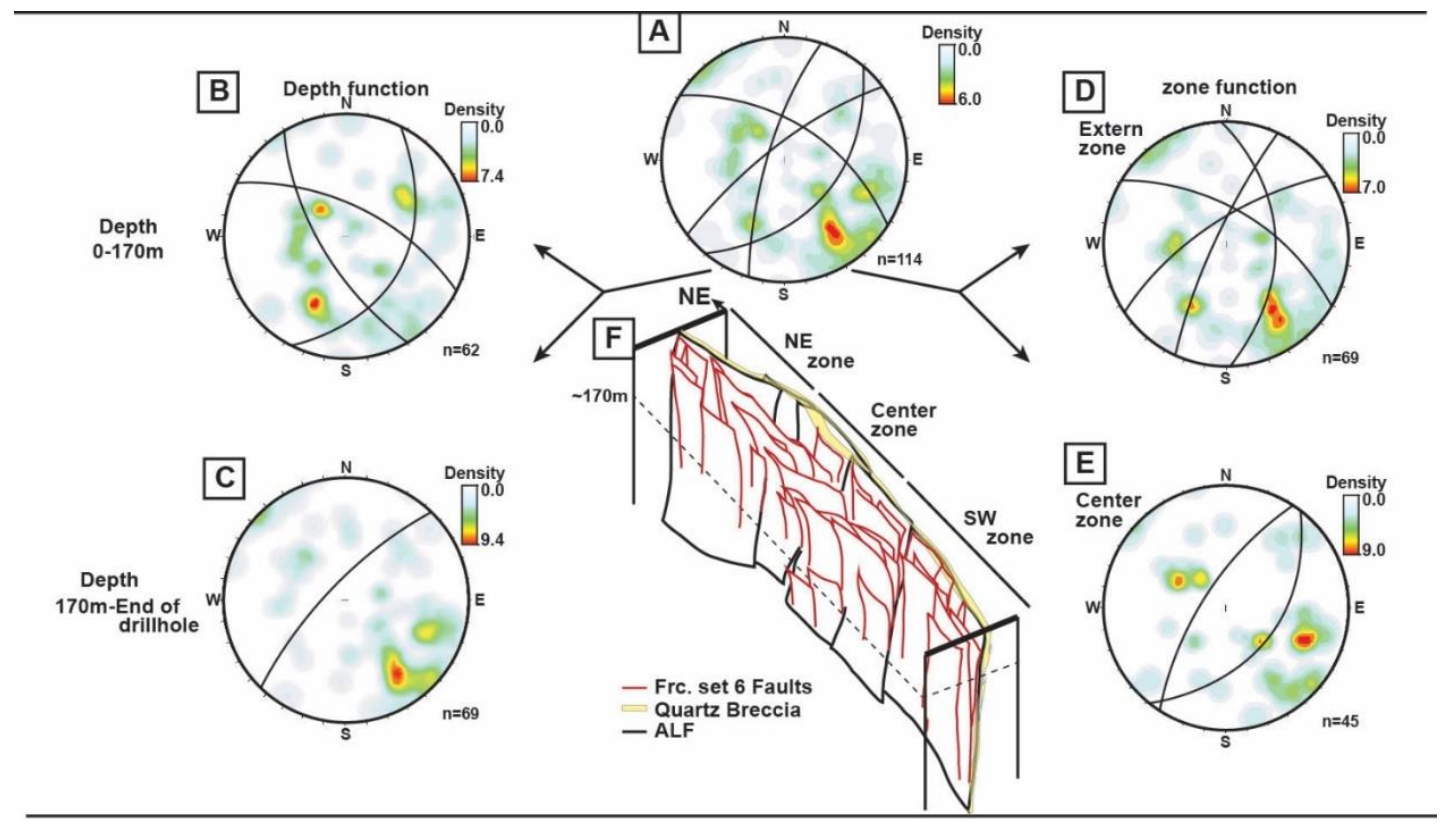

Figure 13: Fracturing stage f6a. A) All oriented fault data sets. B) Depth selection for oriented data. Faults above $170 \mathrm{~m}$ display two directions, NE-SW and NW-SE; C) faults below 170m have a dominant $\mathrm{N} 40^{\circ}$ trend, steeply dipping to the NW. D) Zone selection for oriented data. Faults in the outer zones are dominantly subvertical or dip steeply to the NW; E) Faults in the Center Zone display synthetic dip directions, one to the SE, and a steeper one to the NW. Outer zones correspond to northwest and southeast zones. F) Simplified sketch of the inferred spatial organization of f6a faults, flower type fault geometry. Schmidt's lower hemisphere plot.

Below $170 \mathrm{~m}$, the dominant fault set is better defined along a NE-SW trend, with steep dip to the NW (Fig. 13C). Faults in the Center Zone display opposing dips (Fig. 13E), while in the outer zones faults are dominantly sub-vertical or dip steeply to the NW. This complex arrangement is sketched in figure 13F. 
4.5.2. Fracturing stage $6 \mathrm{~b}$ : second generation of calcite veins

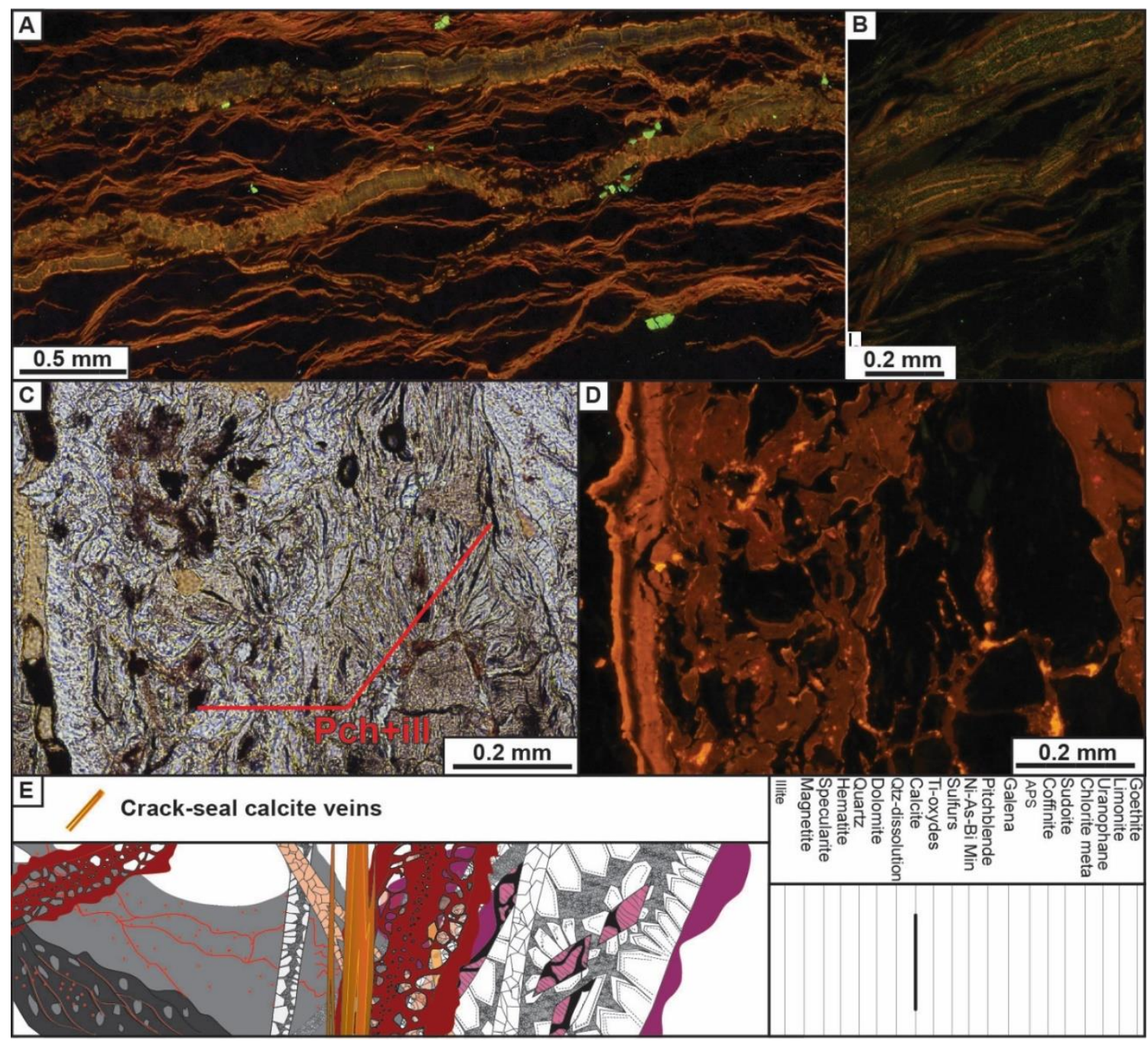

Figure 14: Fracturing stage f6b: A) Cathodoluminescence microscopy photograph showing crackseal calcite fractures. B) Cathodoluminiscence microscopy photograph. Zoom in a crack-seal fracture exhibiting calcite banding. C-D) Optical and cathodoluminescence photographs respectively of vein in D. Reworked pitchblende is observed as micro-clasts. E) Sketch depicting the textural features with the paragenesis characterizing this fracturing stage.

This fracturing event (f6b) is characterized by a second generation of calcite veins. These veins are anastomosed and the calcite is dark orange to yellowish (Fig. 14A). Cathodoluminescence microscopy observation reveals calcite crack-seal (as defined by Bons et al., 2012) (Fig. 14B). The crack-seal mechanism, together with the orthogonal to the vein edges growth of calcite crystals support a dominant opening mode (mode I). These calcite veins crosscut hematized cataclastic faults of the f6a (Fig. 14C) and locally contain reworked microclasts of the mineralized veins of the first stage of mineralization (f5) (Fig. 14D, E). No oriented 
data are available for these veins that were only observed microscopically and characterized under cathodoluminescence.

\subsubsection{Fracturing stage $6 c$ : second stage of uranium mineralization}

At this stage (f6c), uranium mineralization occurs in faults of the f6a stage after the calcite event f6b (Fig. 15A). Mineralization is associated with a phase of illite and sudoite alteration (Fig. 15 and 16, Table 1), and is medium grade (i.e. $3.06 \% \mathrm{U}_{3} \mathrm{O}_{8}$ over $4 \mathrm{~m}$ ). Macroscopically, the mineralization consists of spherulitic pitchblende within fault cataclasites, coating fractures, and leaking out into the foliation in altered host rocks associated with clay alteration (Fig. 15A-C). The spherules of pitchblende are typically rimed by a halo of iron removal or bleaching (Fig. 15B and $\mathrm{C}$ ). This characteristic rim of bleaching is linked to the pitchblende precipitation process itself with transfer of electrons between $\mathrm{Fe}^{2+}$ and $\mathrm{U}^{6+}$ : $\mathrm{Fe}^{3+}$ travelled very locally and reprecipitated as hematite (Wallis et al., 1985; Alexandre et al., 2006). Microscopically, the spherules are made by pitchblende (clay-shaped) co-precipitated and/or impregnated by finegrained illite (Fig. 16A-B, Table 1). Although sudoite (Table 1) has been observed associated with this pitchblende, illite remains the dominant clay mineral. The ore mineralogy is made of pitchblende, coffinite, and rare occurrences of galena. Locally, pitchblende displays cubic habit, indicating probable replacement of pyrite (Fig. 16B). The arrangement of ore minerals within some fractures often displays anastomosed textures possibly indicating syn-kinematic precipitation (Fig. 16C and D).

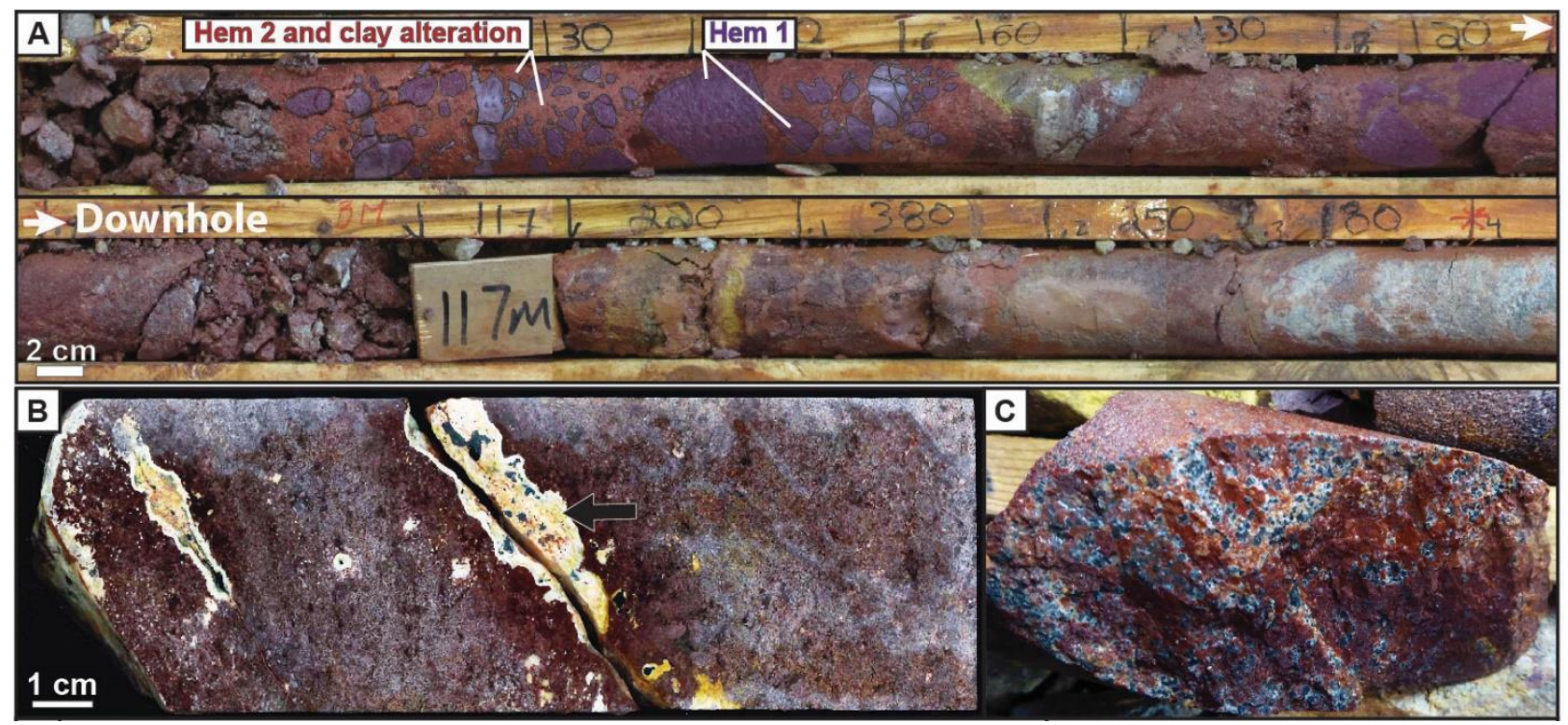

Figure 15: Fracturing stage f6c: A) Drillcore example of a uranium-mineralized cataclastic to ultracataclastic fault rock with reworked purple hematized clasts of the QB, matrix-supported by 
red hematized clay. B) Core sample photograph showing a mineralized fracture. Pitchblende (black spherulites) is altered to secondary yellow crystals of uranophane (black arrow). The white bleaching halo is characteristic of this mineralization stage (see text for explanation). C) Core sample photograph showing a fracture coated with numerous small spherulitic pitchblende rimed with the halo of bleaching.

In comparison with the first stage of uranium mineralization, this second stage shows three main differences: (i) where quartz veins from the $Q B$ are locally re-opened and mineralized, quartz dissolution is more intense (Fig. 16E); (ii) mineralization lacks iron sulfides or other metallic minerals, it is monometallic; and (iii) mineralization spreads far from faults into the host rock (at metre scale) with spherulitic pitchblende, making of this type of mineralization the most extensive ore type in the Contact prospect. Within the mineralized faults f6b, anastomosed calcite veins are locally brecciated and cemented by pitchblende indicating that this mineralization episode postdates f6b (Fig. 16F, G).

Oriented data of mineralized f6c faults display expected similar trends and dip directions (Fig. 17) than non-mineralized f6a faults (Fig. 13), with the same NW-SE and NE-SW two dominant trends. The fracture set $6 c$ and the related uranium mineralization are better developed in the Center Zone where the composite fault zone is wider (Fig. 17). 


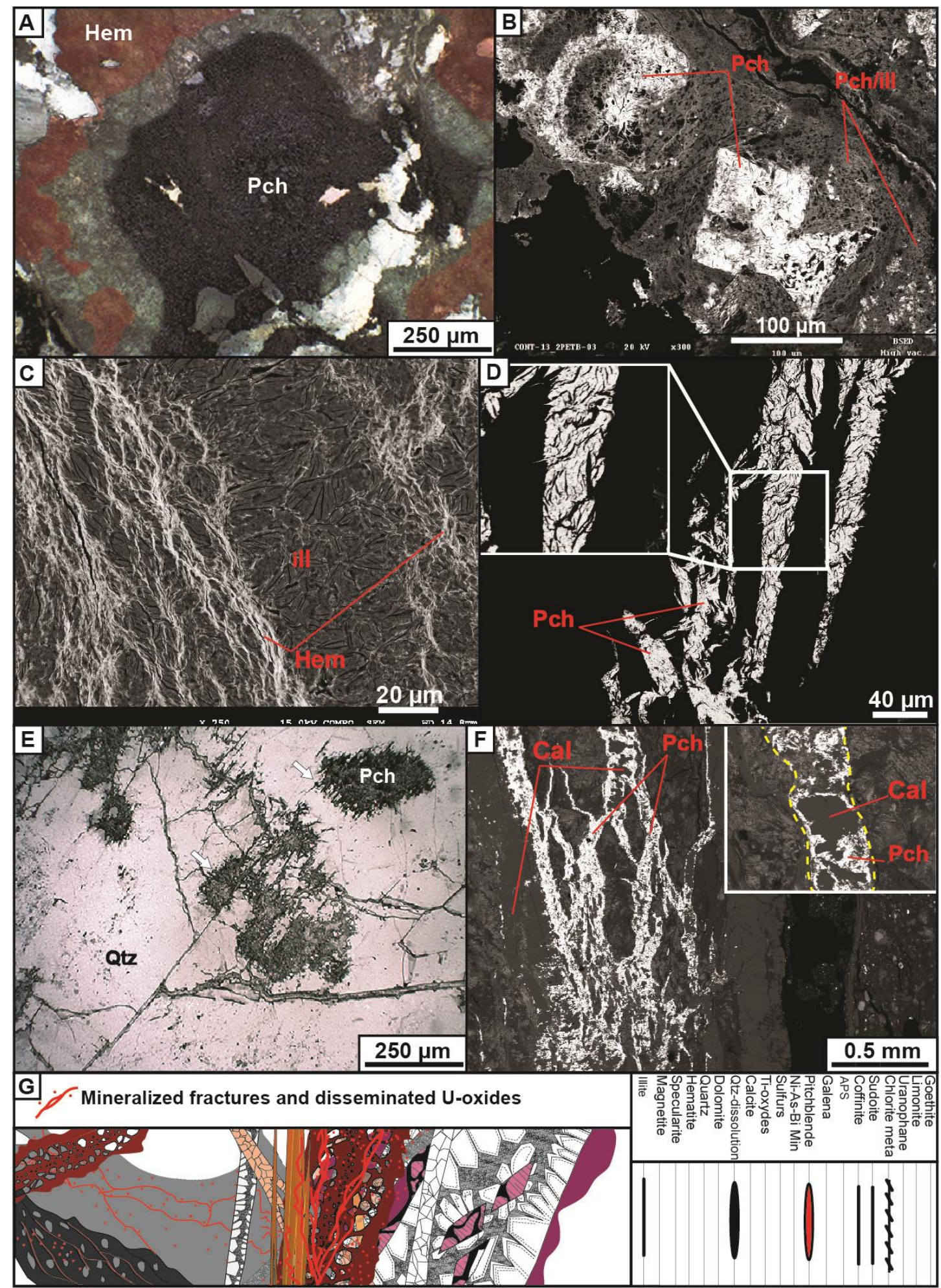

Figure 16: Fracturing stage f6c: A) Transmitted light microscopy photograph. Spherulitic pitchblende surrounded by a halo of bleached hematite. B) SEM photograph showing xenomorphic to cubic pitchblende wrapped by illite. C) SEM photograph showing the anastomosed texture of fractures with hematite and illite typical of the second stage of uranium 
mineralization (6c). D) SEM photograph showing the anastomosed texture of pitchblende infill of anastomosed fractures. E) Transmitted light microscopy photograph showing corroded quartz in a QB vein (white arrows) with pitchblende infilling. F) SEM photograph showing brecciated f6b calcite veins cemented by pitchblende. G) Sketch depicting the textural features with the paragenesis characterizing this fracturing stage

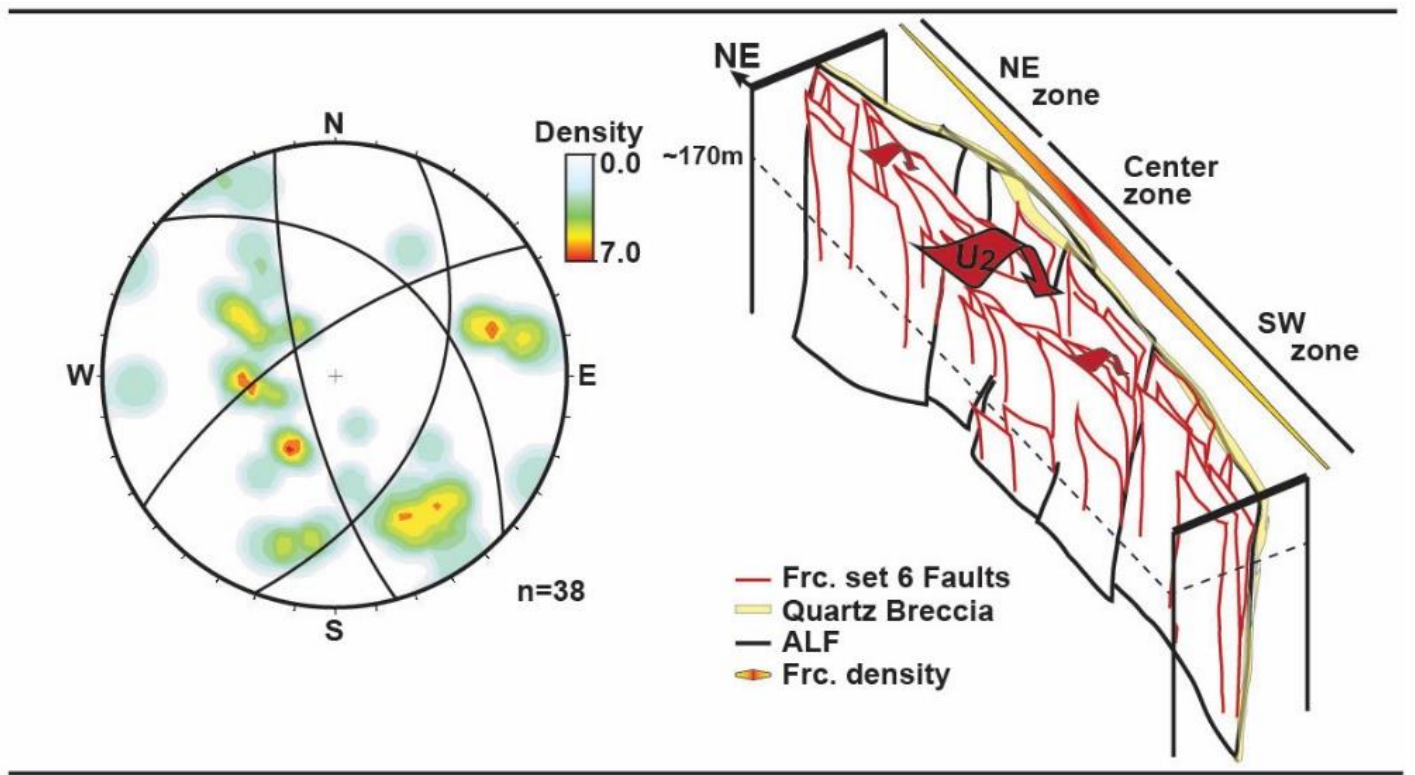

Figure 17: Fracturing stage f6c. Left: Oriented data of $\mathrm{f} 6 \mathrm{c}$ mineralized faults and fractures, second stage of uranium mineralization. Dominant trend is NE, with a secondary NW one. Schmidt's lower hemisphere plot. Right: synthetic cartoon showing the spatial arrangement of the composite f6. Red arrows indicate dominant second stage uranium mineralization better developed in the Center Zone where the composite fault zone is larger.

4.6. Fracturing stages 7 and 8: cataclastic faults and post-primary uranium mineralization alteration

These two faulting stages (f7 and f8) represent the latest major tectonic events observed at the Contact prospect, and both are accompanied by strong clay alteration and removal of iron oxides (bleaching).

The $f 7$ stage is characterized by faults that principally re-activated f6a faults. Fault zones exhibit multi-episodic cataclastic fault rocks with reworked clasts from previously formed fault rocks. Fault reactivation is easily recognizable because fault cores are typically greenish colored as a result of the presence of mint green colored clay (Fig. 18A), in strong contrasts with the 
reddish color of the previously formed iron oxides (Fig. 19A and B). Clay alteration is usually moderate and is characterized by illitization.

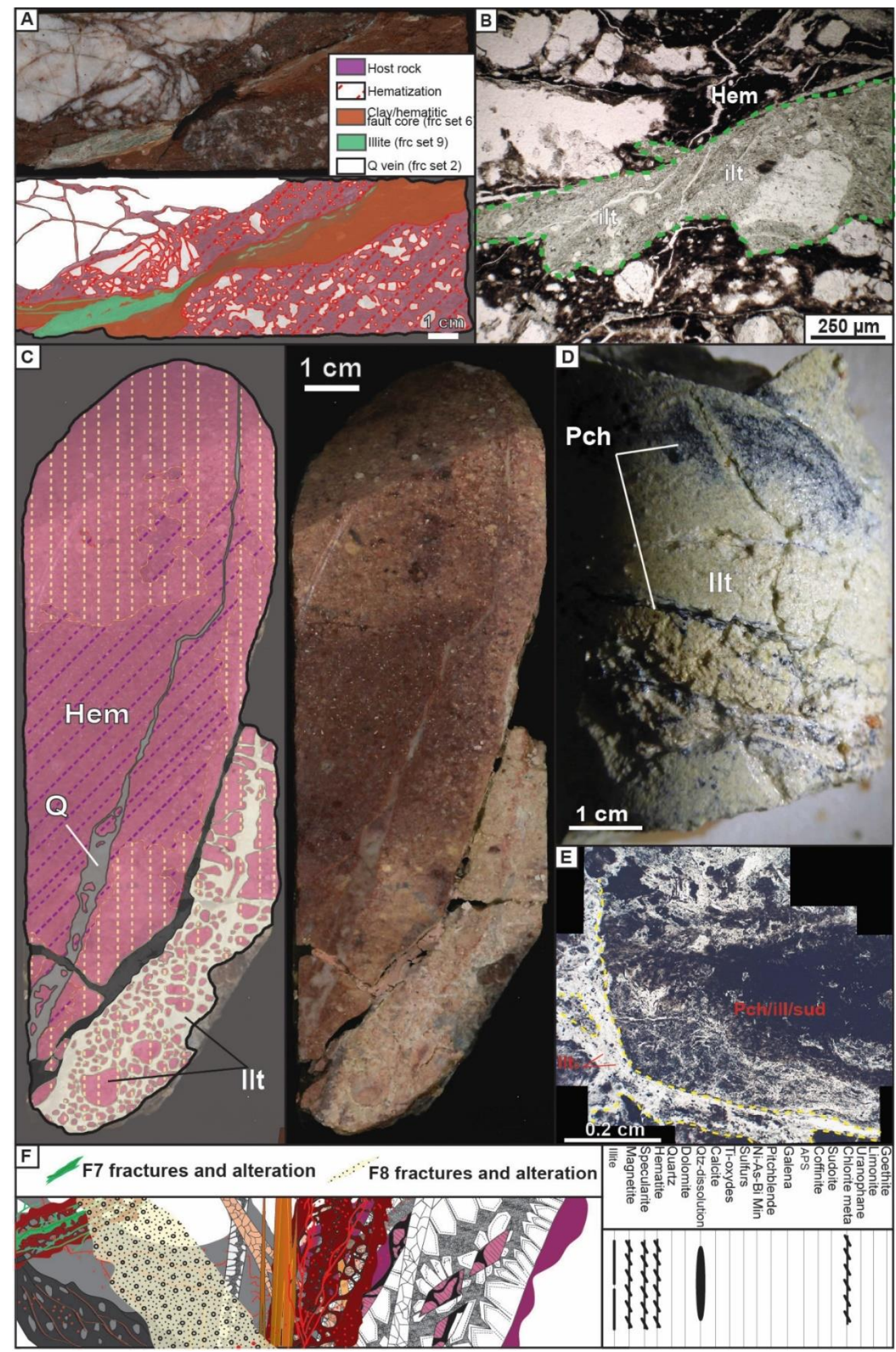

Figure 18: Fracturing stage $f 7(A-B)$ and $f 8(C-E)$ : A) Core sample photograph and interpretation showing the typical aspect of a f6 type fault (cataclastic to ultracataclastic fault, light brown) 
reactivated during stage $f 7$ (mint green ultracataclastic fault rock at the fault core). B) Transmitted light microscopy photograph at the core of the mint green ultracataclasite formed by illite. C) Core sample photograph and interpretation. Typical protocataclastic fault rock with its characteristic white clay alteration (illitization) and bleaching of iron oxides of f6. D) Same as in picture C but involving a mineralized zone. Note that mineralization (black pitchblende) is crosscut by fracture cemented with illite. E) Transmitted light microscopy photograph. Closer view on a reworked clast (yellow line) of second stage mineralization (pitchblende, illite and sudoite), crosscut by fractures cemented with illite. Thin section was made from sample shown in picture D. F) Sketch depicting the textural features with the paragenesis characterizing this fracturing stage

Chlorite minerals were not observed, suggesting that the particular mint greenish alteration color of $\mathrm{f} 7$ might be the result of fine crushing of retrograde metamorphic chlorite (Table 1, $f 7$, relict of chlorite analyzed in a greenish cataclastic fault rock). In addition, the greenish color could also be due to a fine intergrowth of sudoite and illite. The f8 stage is characterized by strongly clay altered protocataclastic (Fig. 18C) to cataclastic fault rocks that crosscut and rework previously formed fractures and ore-bodies (Fig. 18D and E). Fluids driven by these fractures destabilized and removed earlier iron oxides and dissolved and illitized (table 1) other minerals such as chlorite and quartz, thus giving a completely bleached aspect to the rock (Fig. 18D). The whitening illitic clay alteration accompanying $f 8$ is observed as the strongest alteration in the Contact area like in all other Kiggavik deposits, producing destabilization and desilicification of most minerals of the host rock, even leading to a complete argillization of the rock. Therefore it is placed chronologically after the greenish illitic alteration of $f 7$.

The relative chronology between $\mathrm{f} 7$ and $\mathrm{f} 8$ is unconstrained because crosscutting relationships were not observed at any scale, but both crosscut, thus postdate, the second mineralization stage (Fig.18F). Both fracture sets are similar in clay mineralogy with strong illitization.

Oriented data for $f 7$ and $f 8$ are shown in Figure 19. Mint greenish illite faults (f7) are oriented NE-SW in the NE Zone, and NW-SE to N-S in the SW Zone (Fig. 19A). Strongly whitening clay altered fractures (f8) are oriented N-S and NW-SE in the Center Zone, and NE-SW to E-W in the NE Zone (Fig. 19B).

4.7. Fracturing stage 9: uranium remobilization and supergene alteration (third stage of uranium mineralization) 
This stage (f9) is characterized by the local re-concentration of earlier mineralization along reduction-oxidation (redox) fronts marked by the separation between two zones (Fig. 20A-B): one oxidized, reddish to orange, with hematite and goethite (low-temperature iron oxide) minerals and the other reduced, grey, with pitchblende and pyrite. This episode constitutes the third uranium mineralization stage. Mineralization is low to high grade, depending on the remobilized uranium stage, and is only locally present at the Contact prospect. This stage is also characterized by alteration of tetravalent pitchblende and uraninite to secondary hexavalent uranium minerals, like uranophanes and autunite (Fig. 20C) and by alteration of iron oxides with the formation of dusty, yellow limonite coating fractures (Fig. 20D). Although this stage of mineralization is often observed spatially related to limonitic joint corridors, no reliable oriented data could be obtained. Nevertheless, the scattering of oriented data for limonitic joints (Fig. $20 \mathrm{E}$ ) reflects the reactivation of preexisting fractures as passive conduits for a likely downward flow of oxidizing supergene fluids (Fig. 20F).

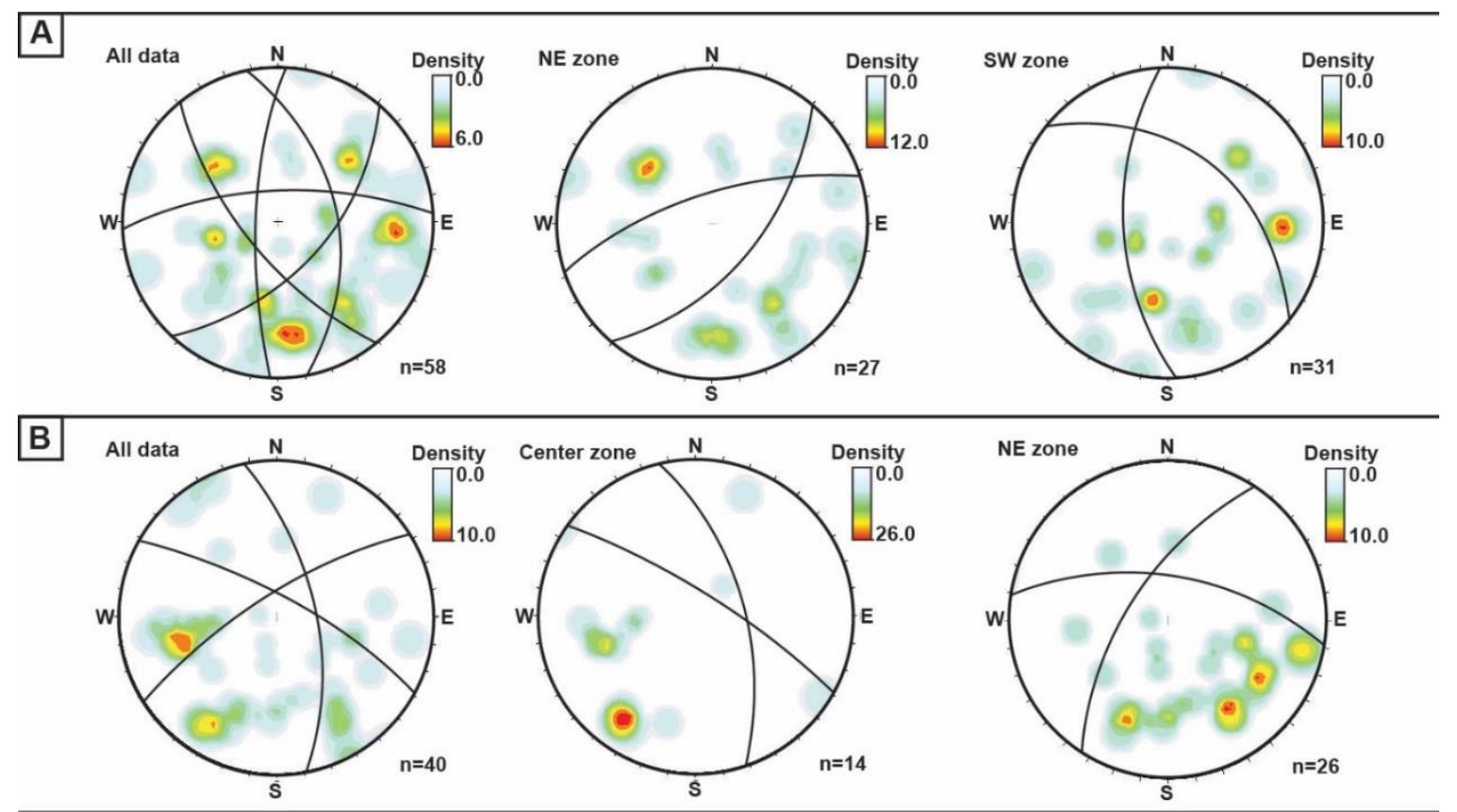

Figure 19: A) Oriented data for faults of $\mathrm{f7}$. No oriented data are available for the Center zone. B) Oriented data for faults of f8. No oriented data are available for the SW zone. Schmidt's lower hemisphere plot.

4.8. Fracturing stage 10: weak fracture reactivation and latest recognizable alteration (bleaching)

The f10 stage is characterized by a weak bleaching of the host rock (Fig. 20A). This bleaching is fracture-controlled, spreads out along the foliation and produces local zones where 
iron oxides oxides were destabilized, remobilized and likely re-precipitated locally (orange goethite). This stage is the latest stage of fracturing and alteration observed at the Contact prospect (Fig. 20F).

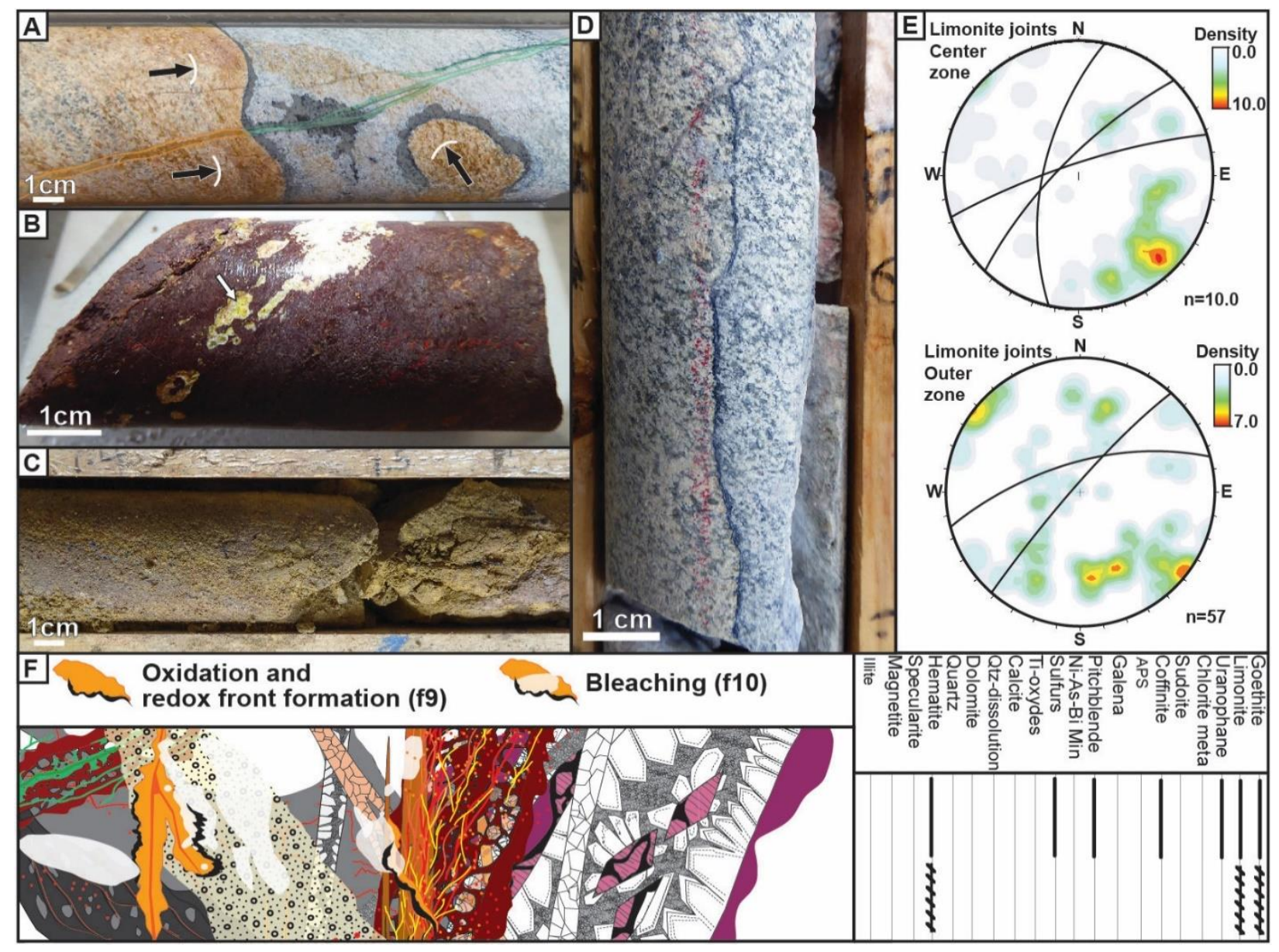

Figure 20: Fracturing stage f9 and f10: A) Drillcore showing redox fronts inducing remobilization of uranium from the first mineralizing stage (stage 5 ) and re-concentration at the front boundary between the orange oxidized zone (goethite) and the grey reduced zone. Uranium mineralization is in dark grey. B) Drillcore displaying supergene alteration of spherulitic pitchblende (the second stage of mineralization here) to uranophane. C) Drillcore showing supergene alteration of the granitic gneiss characterized by dusty limonite spreading out from fractures. D) Drillcore showing a bleached redox front with remobilized pitchblende but without iron oxides. E) Oriented data for joints (fracture set 9) coated with limonite. Schmidt's lower hemisphere plot. F) Sketch depicting the textural features with the paragenesis characterizing this fracturing stage 


\section{Discussion}

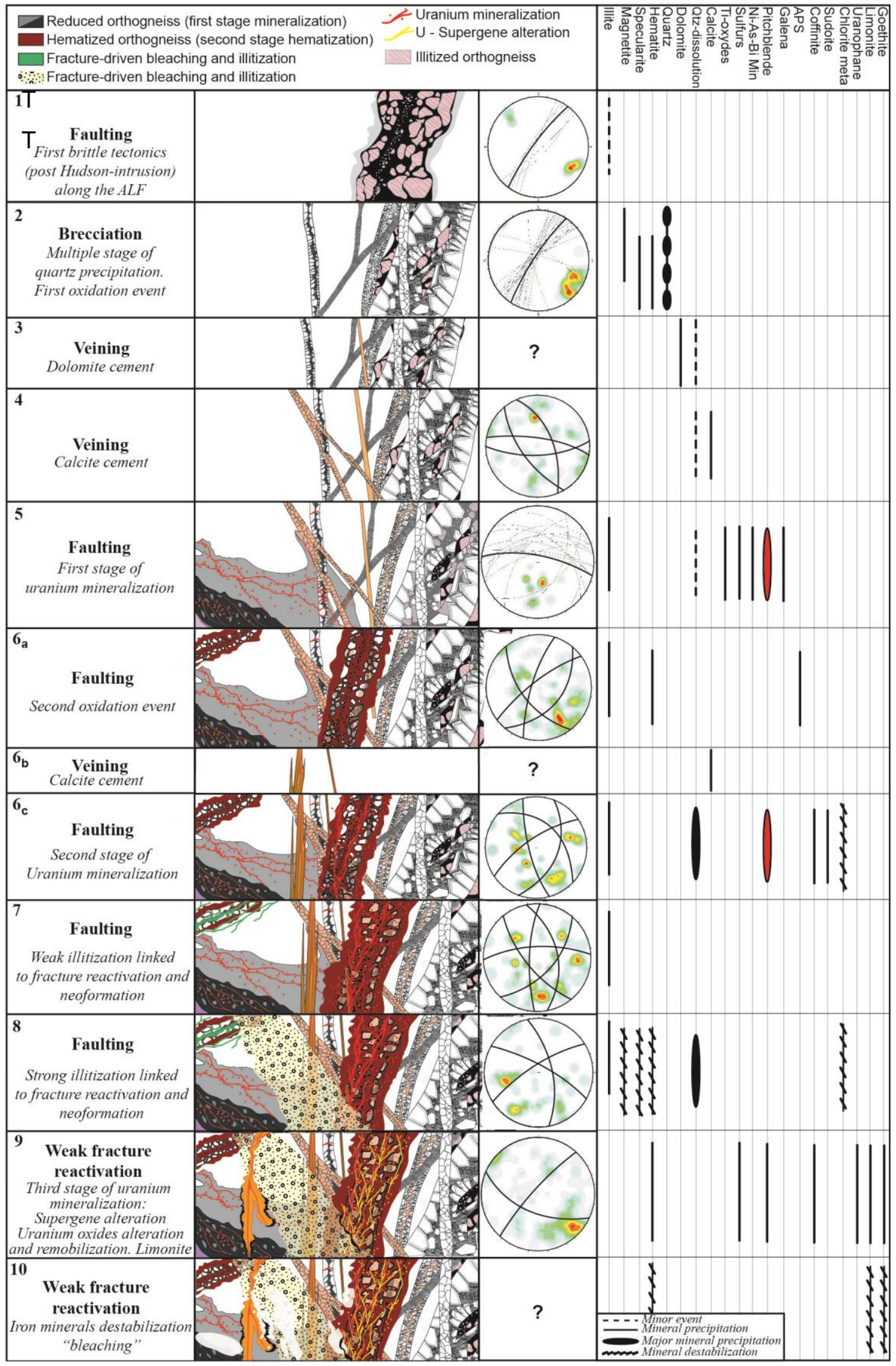


Figure 21: Sequence of structural/microstructural events at the Contact prospect recognized from macroscopic, microscopic, cathodoluminescence and SEM observations. Oriented fracture data in the third column are plotted on Schmidt's lower hemisphere, equal area projection. Mineral paragenesis associated with either mineral precipitation or destabilization is indicated on the last right column.

The identifying characteristics of fracture sets, mineralization and alteration along with the reconstruction of relative chronology (fig. 21) on the basis of observed crosscutting relationships among oriented data allows for the first time in the Kiggavik region to accurately determine the structural controls of uranium mineralization and alteration at the Contact prospect. The synthesis of the fracturing events at the Contact prospect is summarized chronologically in Figure 21, along with oriented data and mineralogical paragenesis. Figure 22 summarizes the main lithological and structural characteristics of the prospect, both in map view (Fig. 22A) and in serial cross sections (Fig. 22C).

As shown on the interpretation of the airborne and ground magnetic maps (Fig. 22B), the ALF is the major structural trend in the area. It runs along the eastern edge of the Hudsonian granite (Fig. 2) and hosts, among others, the Contact prospect (Fig. 2). The Contact prospect is located in the relay zone between the two overlapping AFL fault segments (Fig. 22B). No evidence of ductile or ductile-brittle shear zones was found within the ALF in the Contact prospect.

Furthermore, the ALF likely corresponds to a crustal-scale discontinuity as on the western side of the Kiggavik area the SLIC (Hudson and Nueltin granites) displays a clear NEtrending ellipsoidal shape on aeromagnetic maps (Tschirhart et al., 2013; 2017), which suggests that its emplacement was controlled by a structural discontinuity probably reactivated during the rift episode and deposition of the Baker Lake and Wharton groups. This first fracturing stage is probably linked to the extensional to transtensional tectonics that controlled deposition of these formations between $1850 \mathrm{Ma}$ and $1750 \mathrm{Ma}$ (Hadlari and Rainbird, 2011).

\subsection{Role and timing of the QB}

The QB is a regional feature that has been recognized in the Contact prospect in all drill holes along the ALF (Fig. 22). The silicification-brecciation event is a key element in the structural analysis which additionally constrains the timing of fracturing and mineralizing events. The fact that (i) quartz fractures of the $\mathrm{QB}$ were reactivated at the two main mineralizing 
fracturing stages $f 5$ and f6; (ii) fracturing stages $f 5$ to $f 10$ have only been recognized within the hanging wall of the QB, and the mineralization as well (Fig. 22); and (iii) the prospect footprint is parallel to the NE-trending ALF, as depicted in Fig. 22A, supports the role of the QB as a mechanical pre-existing discontinuity that has been tectonically reactivated several times, has strongly partitioned deformation and focused mineralizing fluid flow, leading to greater uranium concentrations at the Contact prospect. On the basis of drillcore oriented data from the QB veins (Fig. 6) and outcrop observations (Fig. 5A), the QB appears to underline a complex fault zone made of major NE-trending fault segments and step overs with complex fractured relay zones in which veins are oriented ENE-WSW, indicating apparent transtensional right-lateral motion. Segmentation and step overs are responsible for along-strike local changes in directions and thickness of the QB: the breccia is much thicker in the Center Zone where the mineralization is better developed than in the outer zones (Fig. 22C). The role played by the QB as a mechanical discontinuity is also attested by the fact that most of the E-W trending mineralized $f 5$ faults stop eastwards and turn toward a NE trend when connecting to the ALF (Fig. 22A). Such a re-orientation of E-W trending faults is also clear at the regional scale south of the JSF (Fig. 2), whereas north of the JSF all E-W faults delineated from magnetic maps extend farther eastwards parallel to the TF (Fig. 2). The QB therefore behaved both as a mechanical discontinuity and as a transversally impermeable but longitudinally permeable barrier, and therefore exerted the first structural control on Uranium mineralization at the Contact prospect (Fig. 23).

On top of that, the QB constrains the maximum age of the observed mineralization in the Contact prospect. As observed on drillcores, the QB cross-cuts Hudson and Nueltin granites dated ca. $1750 \mathrm{Ma}$ (Peterson et al., 2015b), and on outcrops, the QB is covered by the Thelon Formation, thus bracketing the brecciation / silicification event between $1750 \mathrm{Ma}$ and $1667 \mathrm{Ma}$. The recognition in the QB of microcrystalline mosaic quartz, feathery and ghost sphere growth textures (indicating rapid silica boiling) and crustiform, comb and zonal growth textures (indicating non-boiling fluid conditions) (Bodnar et al., 1985; Dong et al., 1995; Moncada et al., 2012) is typical of geothermal systems (Simmons and Christenson, 1994; Moncada et al., 2012). All these textures show multiple crosscutting relationships indicating that they formed alternatively during the same tectonic phase, and point to an epithermal origin of the QB at the Contact prospect, and more generally in the Kiggavik area. This epithermal origin is also supported by the presence of two groups of fluid inclusions with low temperature-high salinity and high temperature-low salinity, respectively (Chi et al., 2017) as observed in the same type of quartz textures by Turner (2000) and Turner et al., (2001) in the Mallery Lake epithermal Au- 
Ag deposit, 50km south of Kiggavik. The QB occurrence at the Contact prospect thus reflects a major silicification event in the region that predated deposition of the Thelon sandstones at ca. 1750 Ma (Turner et al., 2001; Hadlari and Rainbird, 2011) in a transtensional right-lateral tectonic setting. The first pattern of deformation identified in this work -the f1 brittle faulting that is observed along the ALF- therefore occurred after the Hudsonian intrusive event at $1850 \mathrm{Ma}$ and before the quartz-sealed breccia at ca. $1750 \mathrm{Ma}$.

\subsection{Structural controls and timing of uranium mineralizations}

Three stages of uranium mineralization have been recognized at the Contact prospect. Their timing is inferred from crosscutting relationships and complementary information from the existing literature about uranium deposits at Kiggavik.

\subsubsection{First stage of uranium mineralization}

The oldest stage of uranium mineralization, the fracturing stage f5 (Fig.21), is structurally controlled by faults and related fractures, as well as by micro-fracturing and re-activation of QB veins. Oriented data indicate a dominant E-W strike for the mineralized faults and a NW-SE and E-W strike for the associated fractures; secondary directions are ENE-WSW and ESE-WNW (Fig. 11). Re-activated, orthogonally micro-fractured and mineralized quartz veins of the $Q B$ show dominant NE-SW and minor NW-SE trends (Fig. 11), consistent - as expected- with oriented data for quartz veins of the QB along the ALF (Fig. 8C). Locally, mineralization is associated with dolomite-calcite veins, which display NW-SE and E-W trends; complementary observations in drillcores from other deposits in the Kiggavik area, for instance occurrence of stepped calcite veins with similar orientations (Grare et al., 2017), allows the interpretation of this set of fractures as right-lateral shear veins (mixed mode I-mode II veins). The E-W trending, Thelon-type faults are the second structural control in the Contact prospect. They formed as right-lateral strike-slip faults in response to a compressional stress oriented approximately WNW-ESE (Anand and Jefferson, 2017; Johnstone et al., 2017). Such kinematics was also recorded in the ENE-WSW Thelon fault, during and after deposition of the Thelon Formation (Anand and Jefferson, 2017). As already mentioned in Section 5.1, most of these E-W trending mineralized f5 faults stop eastwards and connect to the ALF, while turning toward a NE trend (Fig. 22A), which explains the reactivation of the QB veins and the change in orientation of part of the fractures moving NE-ward. 


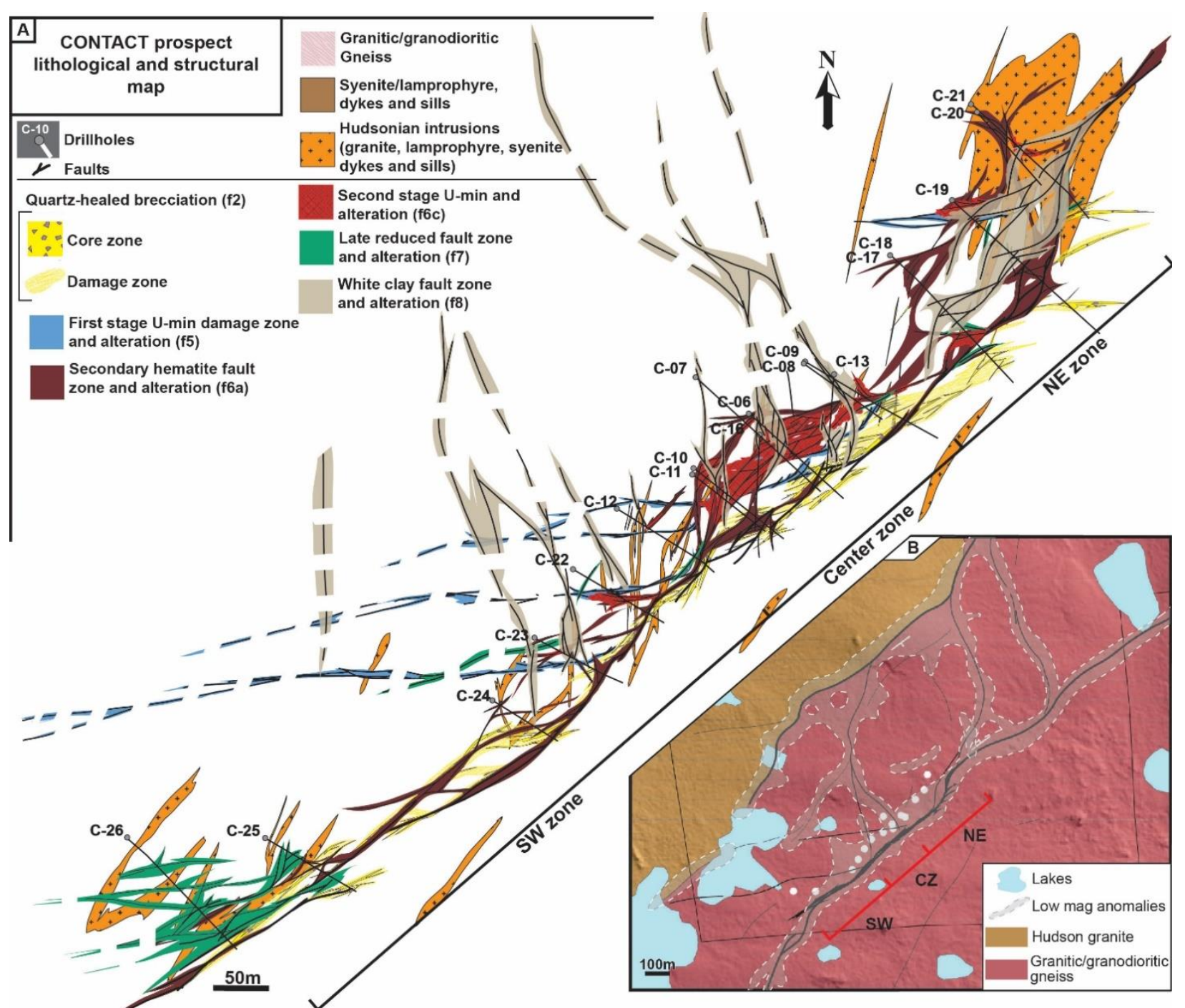

Figure 22: A) Lithology and structural map of the Contact prospect. Fractures sets $f 1, f 5, f 6, f 7$ and $f 8$ are represented, including the two stages of primary uranium mineralization (f5, f6c); the other fractures sets are not represented due to the small scale of related fractures or because they could not be linked to any major fault. B) Insert map of the local cartographic organisation of the ALF, location of the drillholes (white dots) and connections between the northern and southern branches of the ALF. C) Serial NW-SE oriented sections across the Contact prospect. Holes Cont-04 and Cont-05 were drilled by former company exploring the Kiggavik area, they are vertical and do not display any oriented data. Furthermore, they do not crosscut any uranium mineralization. Set f8, which drives white clay alteration, consists of NNW faults steeply dipping to the East and NE in the Center zone, so they appear with an apparent shallow dip on NW crosssections. 

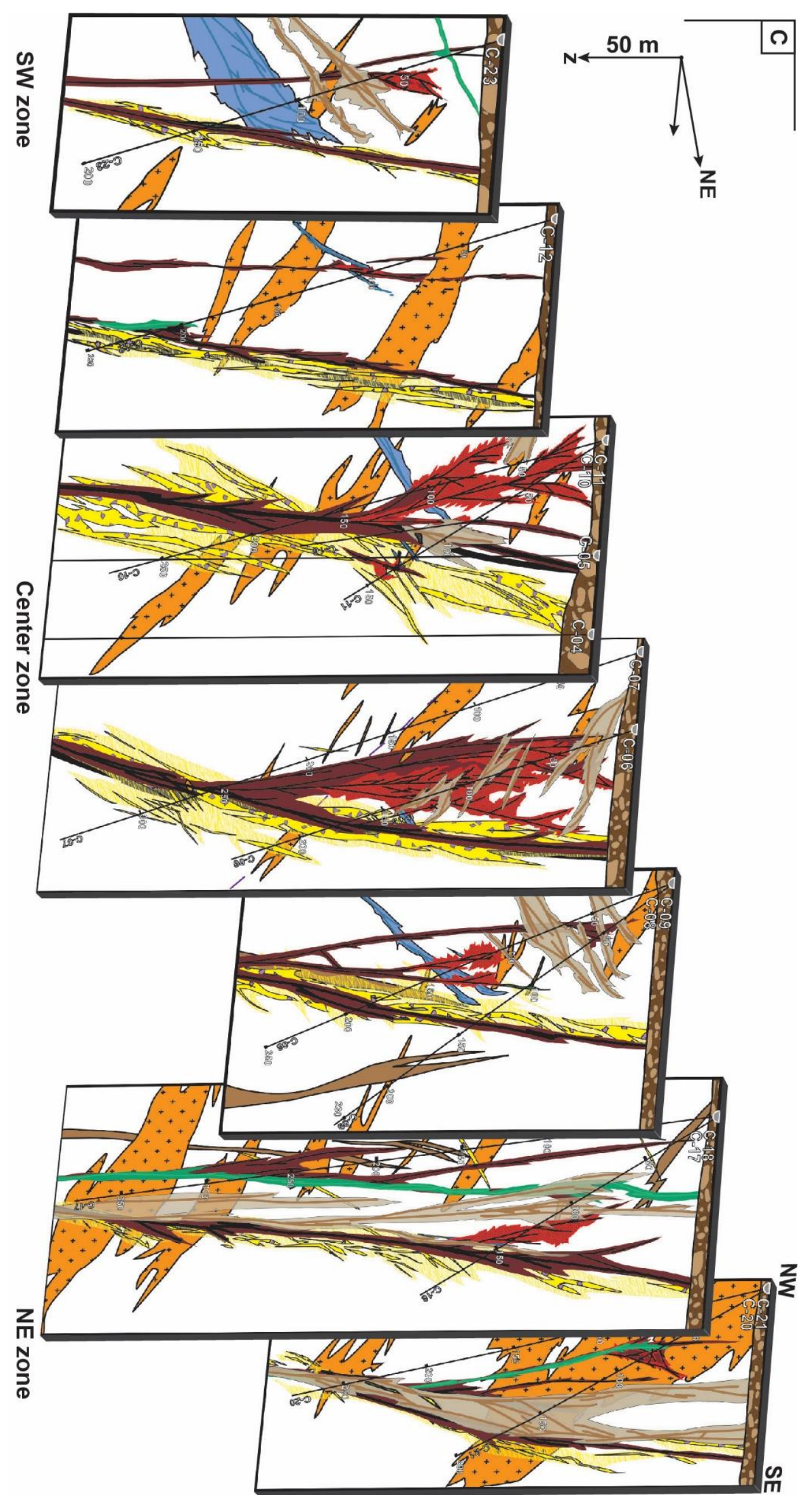
At the Contact prospect, the first stage of uranium precipitation (f5) corresponds to a polymetallic mineralization with pitchblende, coffinite, uraniferous titanate, titanium-oxides with pitchblende micro-inclusions, sulfides (pyrite, chalcopyrite and bravoite), occurrences of native bismuth and unidentified As-Ni-Co $(+-\mathrm{U})$ compounds, whereas the second $(\mathrm{f} 6 \mathrm{c})$ and third stages (f9) correspond to monometallic mineralization with pitchblende, coffinite, rare occurrences of galena and pyrite. Rutile, brannerite-like and uraniferous titanium-bearing minerals are not common minerals in unconformity type mineralization in the Athabasca Basin deposits (e.g., Jefferson et al., 2007). Furthermore, the polymetallic mineralization described in the Athabasca uranium deposits are sandstone-hosted (e.g., Cigar Lake and Midwest deposits), while mineralization hosted in basement are predominately monometallic (e.g., McArthur River and Eagle Point deposits; Ruzicka, 1989; 1996; Jefferson et al., 2007). Brannerite is described as related to pre-Athabasca mineralizing events in the Beaverlodge District (Dieng et al., 2013), in the Baker Lake Basin (Miller, 1980), and at the Karpinka uranium prospect in the southern Athabasca Basin (Williams-Jones and Sawiuk, 1985). By analogy, the presence of brannerite minerals in the first stage of mineralization at the Contact prospect may therefore reflect a preThelon uranium source, probably an evidence of relict "magmatic" uranium mineralization present at Contact, described in other deposits of the Kiggavik area (Grare et al., 2017), and remobilized by hydrothermal fluids during the first mineralizing stage. F5 postdates the formation of the QB, which is bracketed between $1750 \mathrm{Ma}$ and $1667 \mathrm{Ma}$, and thus constrains this mineralization to be younger than $1667 \mathrm{Ma}$. Pitchblendes within quartz veins reveal U-Pb isotopic ages of $1403 \pm 10 \mathrm{Ma}$ (Farkas, 1984) at the Kiggavik Main Zone and of $1520 \pm 79 \mathrm{Ma}$ at the Bong deposit (Sharpe et al., 2015). The age of ca. $1500 \mathrm{Ma}$ is the age of the emplacement

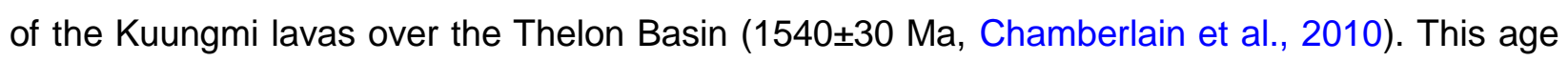
was obtained in several studies throughout the Western-Churchill province (Turner et al., 2003; Bridge et al., 2013; Gandhi et al., 2013; Dieng et al., 2013; Sheahan et al., 2015) and is possibly linked to a regional thermal event possibly reflecting a craton-scale process. If this thermal event has reset the U-Pb isotopic system (Davis et al., 2011; Peterson et al., 2015b), then the ages of the first stage of faulting and mineralization could be bracketed between ca. $1667 \mathrm{Ma}$ and $1420 \mathrm{Ma}$; although this remains speculative to date. 


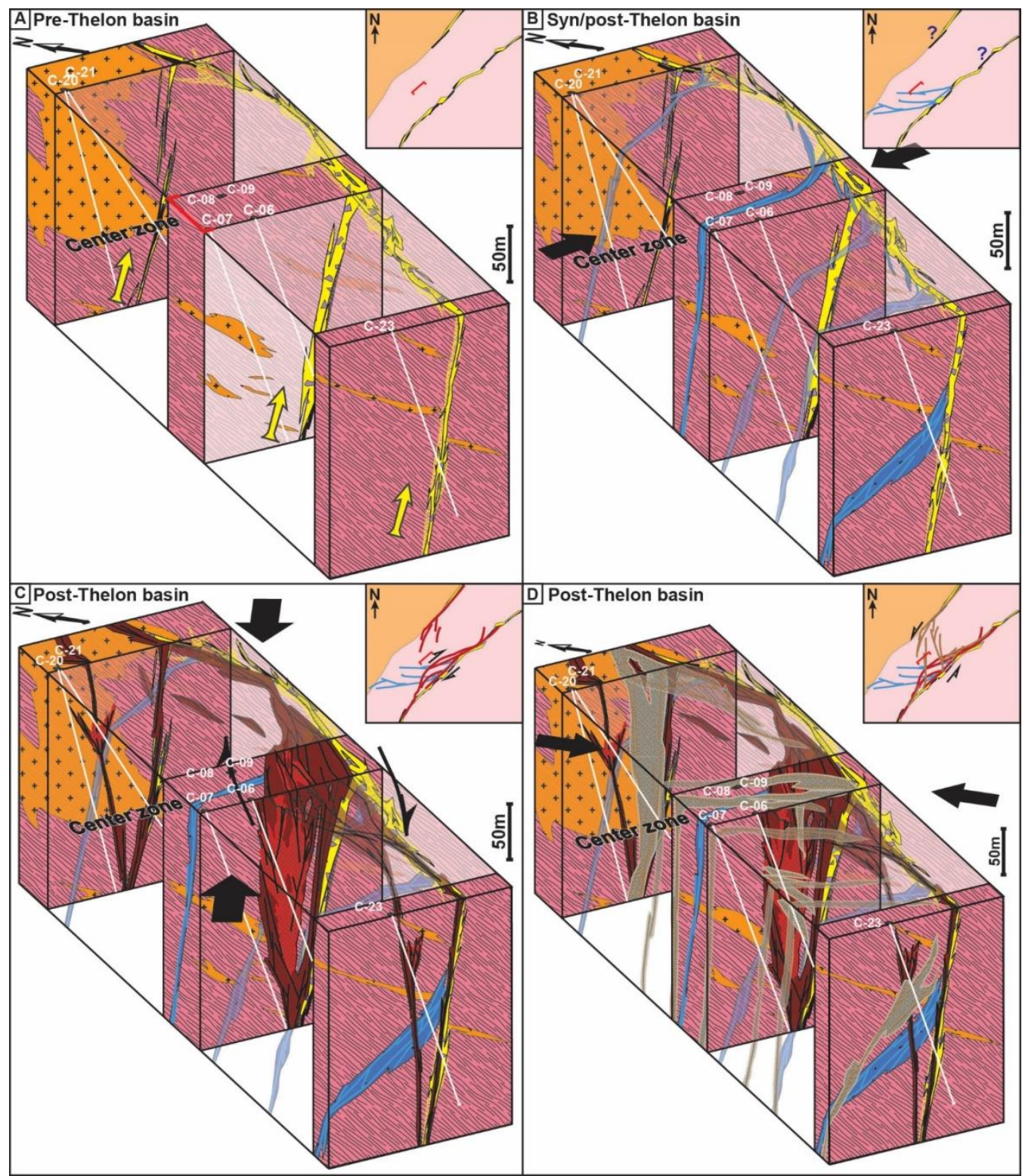

Figure 23: 3D synthetic blocks of the Contact prospect with the main fracturing stages depicted. A) Quartz breccia (f2) along the NE-SW ALF. B) First stage of uranium mineralization (f5). C) Second stage of uranium mineralization (f6). D) Late clay alteration (f8), reworking uranium mineralization of stages 1 and 2.

\subsubsection{Second stage of uranium mineralization}

Stage f6 corresponds to a new tectonic event responsible for the second stage of mineralization at Contact. This event can be divided into three sub-stages, f6a to f6c, because of the close spatial relationships and the same typological characteristics of the fracture sets (Figs. 12 and 15). As explained above, the sub-stages f6a and f6c display strong similarities in fault rocks, alteration type and oriented data (Figs. 13 and 17), but are separated by a sub-stage 
of calcite vein formation, f6b, and mineralization only occurs in $f 6 c$ veins (Fig. 15). Although a $\mathrm{NE}$ trend of $\mathrm{f} 6$ fracture set is dominant (Fig. 13), this fracture stage displays a more complex spatial architecture than the 55 that drove the first stage of mineralization, with conjugate NWtrending fractures (Fig. 17), conjugate dip directions particularly in the Center Zone, and anastomosing fault arrangement mimicking the anastomosed geometries observed at the microscale (Fig. 16C and D). On the basis of drillhole correlation and oriented data, we deduce that faults become vertical at depth, whereas all fracture sets turn to the NE and connect at depth to the ALF (QB) zone (Figs. 22C and 23). This occurs specifically in the Center Zone, making it a wider fractured zone, which likely enhanced fluid circulation and uranium precipitation. As fractures density decreases when moving from the Center to the outer zones, mineralization does too (Fig. 22). We consider that sub-stages f6a, $b$ and $c$ are synchronous of the same tectonic phase, corresponding to successive tectonic pulses. The lack of kinematic indicators prevents any determination of the precise kinematics for this fracture stage. Nevertheless, the cartographic organisation suggests it has occurred under right-lateral strike-slip kinematics of the ALF (fig. 23) enhancing local fluid circulation. This would be consistent with the NE-SW oriented compression prevailing at this stage (Grare et al., 2017) as deduced from other places in the Kiggavik area, causing dextral motion along the reactivated ALF. This tectonic phase and the related reactivation of the ALF are considered as the third structural control of mineralization at the Contact prospect.

Other studies of the Kiggavik deposits have described and dated pitchblende with characteristics similar to those of the second stage of uranium mineralization (f6c) in Contact; $\mathrm{U}$ $\mathrm{Pb}$ isotopic ages range between ca. 1200 and $1300 \mathrm{Ma}$ with various episodes of pitchblende precipitation (Shabaga et al., 2017a, b; Ashcroft et al., 2017). Additionally, at the Kiggavik Main Zone deposit, the orebody is cut by the 1267 \pm 2 Ma Mackenzie dikes (Fuchs et al., 1986; Lecheminant and Heaman, 1989). Therefore this second mineralizing stage would be older than the Mackenzie intrusive event, being therefore bracketed between ca. $1500 \mathrm{Ma}$ and $1270 \mathrm{Ma}$. The presence of sudoite (Table 1) in the mineralogical association with uranium minerals within f6c fractures fingerprints the circulation of basinal brines (Percival et al., 1989; Renac et al., 2002; Beaufort et al., 2005). Unfortunately, our study does not allow determining whether this basinal fluid introduced more uranium into the system or just remobilized the pre-existing mineralization due to the oxidizing nature of brines (Fayek and Kyser, 1997; Cuney, 2005). However, basinal brines would have likely leached uranium from the various stocks available in the Kiggavik area: metamorphosed epiclastic rocks of the Puqik Lake Formation (Johnstone et al., 2017), rhyolitic flows of the Wharton group (Blake, 1980; Peterson et al,, 2015a), 
fluorapatite-cemented breccia at the base of the Thelon Formation (Davis et al., 2011), Uenriched intrusions (Scott et al., 2012) and/or much more probably the uranium concentrated during the first stage of mineralization.

Cathodoluminescence observations on quartz in mineralized zones reveal haloes with distinct colors (yellow-red) around fracture-bearing ore minerals. This phenomenon, known as irradiation halo, is due to the structural modification of quartz linked with the travel of an alpha particle through the crystal lattice (Meunier et al., 1990; MacRae et al., 2013), inferred as being due to uranium remaining in contact with quartz crystal or uraniferous fluid flow through the fracture. As such, even when uranium minerals are no longer observable (i.e., due to later remobilization), this interaction between quartz and uranium allows assessing whether or not uranium was present in the host rock or in fluids that circulated through a fault zone.

\subsection{Post-primary ore fracturing and alteration}

Two faulting stages occurred after fracturing stages $\mathrm{f} 7$ and $\mathrm{f} 8$. They represent the latest major tectonic events observed at the Contact prospect, and both are accompanied by strong clay alteration and iron oxides bleaching. Oriented data for f8 display NE-SW and NNW-SSE set trends. The first trend is interpreted as related to the reactivation of the previously formed $f 6$ faults, while the second would correspond to newly formed faults. N-S faults highlight the formation of a hard-linked overlapping step over through the final branching of both fault segments of the ALF leading to the present-day architecture of the relay fault zone array (Fig. $22 \mathrm{~A}$, regional insert-map). We speculate that this fault relay zone developed in response to leftlateral strike-slip kinematics, favoring connection of the two branches of the ALF and enhancing circulation of acidic, reducing fluids. Such kinematics could have occurred in response to a NNW-SSE oriented compression (Fig. 23).

Interestingly, the reducing fluids that circulated thanks to fault reactivation and new rock fracturing at stage 8 caused intense desilicification, illitization, and bleaching of the host rocks through dissolution and destabilisation of iron-bearing minerals (mainly chlorite and hematite). This strong argillization altered the original texture of rocks and lowered their electrical resistivity, density and magnetic susceptibility leading to significant geophysical anomalies that facilitated the discovery of the uranium deposits in Kiggavik, including the Contact prospect (see Roy et al., 2017 and references therein). Nevertheless, unlike the classic unconformity-related uranium deposits in the Athabasca Basin where clay alteration haloes around the ore bodies are associated with mineralizing stages (Hoeve and Sibbald., 1978; Hoeve and Quirt, 1984; Fayek 
and Kyser, 1997; Jefferson et al., 2007), the strongest clay alteration event (f8) in the Contact prospect clearly postdates the second stage of mineralization (fig. 23).

The presence of goethite (that usually forms at low temperature), limonite (that usually results from supergene alteration of iron oxides), along with the presence of redox fronts, characterizes the in-coming of supergene, oxidizing, low temperature fluids of meteoric origin (Devoto, 1978; Mercadier et al., 2011) circulating through f9 fractures. It is unknown whether there was only remobilization or also new uranium input at that stage. However, the nature of the circulating fluids, which is very different in terms of chemistry (chlorinity, $\mathrm{pH}, \mathrm{NaCl}$ content) from basinal brines (Richard et al., 2011), makes it unlikely that a new significant uranium input occurred. Moreover, the supergene mineralization is observed locally at the Contact prospect, which indicates that this fluid circulation did not have a significant impact on the grade and extension of the uranium ore body. Although this stage of mineralization is observed often spatially related to limonitic joint corridors, no reliable oriented data could be obtained. Nevertheless, the scattering of oriented data for limonitic joints (Fig. 20E) reflects the reactivation of previously formed fractures and utilisation of other fracture zones as passive conduits for an inferred downward penetration of oxidizing supergene fluids. This stage is considered the fourth structural control in the Contact prospect. The supergene fluid-related mineralization (redox front type) of stage $\mathrm{f} 9$ has been dated in other deposits of the Kiggavik area at ca. $<1200 \mathrm{Ma}$, with various episodes of uranium precipitation between ca. 850 and 500 Ma, as also at ca. 300 and 100 Ma (Farkas, 1984; Sharp et al., 2015; Shabaga et al., 2017a, b; Ashcroft et al., 2017).

A final fracturing event associated with $\mathrm{f} 10$, occurred at Contact and is responsible for postredox front bleaching. The origin and the nature (fluid or gas?) of the reducing fluid remain unconstrained. This bleaching stage does not seem to be associated with any clay alteration, but only with iron-bearing minerals destabilization. Contrary to this, at the Eagle Point uranium deposit in Athabasca, Mercadier et al., (2011) proposed that this bleaching post-redox front was associated with kaolinization and linked to renewed circulation of meteoric-derived fluids.

\section{Conclusions}

This work describes in detail the multi-scale organization of the mineralized fracture network at the Contact uranium prospect and places it into the long polyphase tectonic history of 
the Kiggavik area. This is the first time such a mineralized and non-mineralized fracture network is decrypted and described in unconformity-related uranium deposits hosted within the metamorphosed basement. The identification and characterization of the nature and kinematics of fracture sets along with the reconstruction of the relative chronology on the basis of observed crosscutting relationships, mineral paragenesis, and widespread oriented data allows for identifying four major structural controls. These structural controls can help and guide future exploration in the Kiggavik uranium province to help find new deposits.

Ten fracturing stages ( $f 1$ to $f 10$ ) were identified with three stages directly controlling mineralization. Each of them is characterized by distinct fault rocks, fracture infill, and host rock alteration. The key conclusions are summarized as follows:

1- There is a long lived and polyphase brittle tectonic history in the Kiggavik area, spanning from the emplacement of the Hudsonian Schultz Lake Intrusive Complex at ca. $1850 \mathrm{Ma}$, to the later stages of circulation of supergene meteoric fluids, which has been recorded by various fracture generations overprinting the Andrew Lake Fault (ALF) and before the emplacement of the Mackenzie dikes at $1267 \mathrm{Ma}$. The most significant event that exerted the strongest structural control was the formation of the quartz breccia (QB) at ca. $1750 \mathrm{Ma}$. The QB acted as a mechanical barrier that partitioned deformation and favored later fracturing within its hanging wall. The silicified AFL was also a transverse impermeable barrier for fluids, focusing fluid flow longitudinally (or vertically) dominantly within the hanging wall. This tectonic episode was critical in preparing the impermeable metamorphic gneissic basement for later fluid circulation and uranium entrapment, constituting the first structural control.

2- Three stages of uranium mineralization were determined.

a. Mineralization precipitated during the first stage (f5) is the highest grade (e.g., 4.76 $\%$ U3O8 over $50 \mathrm{~cm}$ ) and is polymetallic with colloform to xenomorph pitchblende and coffinite, uraniferous titanate, titanium-oxides with pitchblende micro-inclusions and sulfides (pyrite, chalcopyrite, and bravoite). Mineralization is associated with quartz dissolution in veins and weak grey clay alteration of the host rock. The uraniumbearing fluids are of unconstrained origin. In this first stage, mineralization is controlled by E-W faults and reactivated, micro-fractured quartz veins of the QB (f2). As the QB is inferred to be bracket between $1750 \mathrm{Ma}$ and $1667 \mathrm{Ma}$, this mineralizing event postdating the QB, has to be younger than $1667 \mathrm{Ma}$. F5 mineralized faults formed in response to a compressional stress oriented approximately WNW-ESE 
leading to right-lateral strike-slip motion along these faults which constitute the second structural control.

b. The second stage of mineralization is controlled by NE-trending, faults and fractures (f6c), which drove oxidizing fluids and partially reactivated, likely under right-lateral strike-slip kinematics, and overprinted the ALF. They constitute the third structural control. Mineralization is low to medium grade (e.g., $3.06 \% \mathrm{U}_{3} \mathrm{O}_{8}$ over $4 \mathrm{~m}$ ) and is essentially monometallic with pitchblende and coffinite. Spherulitic pitchblende is disseminated within fault cataclasites, nearby host lithologies or coating fractures. The spherules of pitchblende are typically rimmed by a halo of iron bleaching and are formed by pitchblende (clay-shaped) co-precipitating with fine-grained illite, locally associated with sudoite. This stage of mineralization is linked to oxidizing basinal brines, following an episode of hematization, and is the most penetrative outward from faults into the host rock. It has not been determined whether the brines remobilized preexisting mineralization or brought new uranium into the system. This tectonic and mineralization event likely occurred between ca. $1500 \mathrm{Ma}$ and $1270 \mathrm{Ma}$.

c. In the third stage, mineralization was remobilized by supergene oxidizing fluids circulating though pre-existing fractures of various orientations and re-concentrated uranium along redox fronts. Mineralization is low to high-grade with secondary uranium minerals, such as uranophane and alteration of iron oxides to limonite. The exploitation of the pre-existing fractures networks as conduits for downward permeating supergene fluids is considered to be the fourth structural control in the Contact prospect. By association with other dating of Kiggavik deposits, this mineralization occurred at ca. $<1200 \mathrm{Ma}$, with various episodes of uranium precipitation between ca. 850 and $500 \mathrm{Ma}$, as also at ca. 300 and $100 \mathrm{Ma}$.

3- Unlike the classic unconformity-related uranium deposits in the Athabasca Basin, in which clay alteration extends as haloes around the ore bodies associated with mineralizing stages, the strongest clay alteration of event f8 postdates the two stages of primary uranium mineralization in the Contact prospect, and seems to have caused significant uranium remobilization. This suggests that the basement-hosted Contact prospect is a relict of what was once a bigger deposit, and that a part of uranium ore could have been remobilized toward the now eroded overlying Thelon sandstones. 


\section{Acknowledgements}

The authors thank AREVA and AREVA Resources Canada for the full financial support and access to the Kiggavik camp and exploration data. Special thanks to Senior geoscientist D. Quirt and geologists R. Zerff, R. Hutchinson, K. Martin, and D. Hrabok for their help and enriching discussions during field work and data interpretation. The detailed reviews by $\mathrm{Dr}$. Stefan Kruze, two anonymous reviewers, and Associate Editor David Lentz, have greatly improved the quality of this paper.

\section{References}

Alexandre, P., Kyser, K., Polito, P., Thomas, D., 2006. Alteration Mineralogy and Stable Isotope Geochemistry of Paleoproterozoic Basement-Hosted Unconformity-Type Uranium Deposits in the Athabasca Basin, Canada. Econ. Geol. 100, 1547 LP-1563

Anand, A., and Jefferson, C.W., 2017. Reactivated fault systems and their effects on outcrop patterns of thin-skinned early thrust imbrications in the Kiggavik uranium camp, Nunavut, Geological Survey of Canada, Open File 7895, 2017, 9 pages (1 sheet), https://doi.org/10.4095/302776

Ashcroft, G.S., Fayek, M.F., Quirt, D., Camacho, A., Jefferson, C.W., 2017. The geochemistry and geochronology of the End Deposit, NE Thelon region, Nunavut Canada: An insight to the Athabasca basin's closest relative. Poster presented at 2017 GAC MAC.

Baudemont, D., Fedorowich, J., 1996. Structural control of uranium mineralization at the Dominique-Peter Deposit, Saskatchewan, Canada. Econ. Geol. 91, 855-874. doi:10.2113/gsecongeo.91.5.855

Baudemont, D., and Pacquet, A., 1996. The Sue D and E Uranium Deposits, Northern Saskatchewan: Evidence for structurally controlled fluid circulation in the Athabasca Basin. MinExpo'96 Symposium. Adv. in Saskatchewan Geol. and Min., 85-94

Beaufort, D., Patrier, P., Laverret, E., Bruneton, P., Mondy, J., 2005. Clay Alteration Associated with Proterozoic Unconformity-Type Uranium Deposits in the East Alligator Rivers Uranium Field, Northern Territory, Australia. Econ. Geol. 100, 515-536. doi:10.2113/gsecongeo.100.3.515

Berman, R.G., Davis, W.J., Pehrsson, S., 2007. Collisional Snowbird tectonic zone resurrected: Growth of Laurentia during the $1.9 \mathrm{Ga}$ accretionary phase of the Hudsonian orogeny. Geol. 35, 911-914. doi:10.1130/G23771A.1 
Blake, D.H., 1980. Volcanic rocks of the Paleohelikian Dubawnt Group in the Baker LakeAngikuni Lake Area, District of Keewatin, N.W.T; Geological Survey of Canada, Bulletin 309, 39p.

Bodnar, R.J., Reynolds, T.J. and Kuehn, C.A. 1985. Fluid inclusion systematics in epithermal systems. In Geology and Geochemistry of Epithermal Systems (B.R. Berger \& P.M. Bethke, eds.) Society of Economic Geologists, Reviews in Economic Geology, 2, 73-98

Bons, P.D., Elburg, M.A., Gomez-Rivas, E., 2012. A review of the formation of tectonic veins and their microstructures. J. Struct. Geol. 43, 33-62. doi:https://doi.org/10.1016/j.jsg.2012.07.005

Bridge, N.J., Banerjee, N.R., Pehrsson, S., Fayek, M., Finnigan, C.S., Ward, J., and Berry, A., 2013. The Lac Cinquante uranium deposit, western Churchill Province, Nunavut Canada. Exploration and Mining Geology, 21: 27-50; doi 0964-1823/00

Bright, S., Conner, G., Turner, A., Vearncombe, J., 2014. Drillcore, structure and digital technologies. Appl. Earth Sci. 123, 47-68. doi:10.1179/1743275814Y.0000000051

Bruneton, P., 1993. Geological environment of the Cigar Lake uranium deposit. Can. J. Earth Sci. 30, 653-673. doi:10.1139/e93-054

Chamberlain, K.R., Schmitt, A.K., Swapp, S.M., Harrison, T.M., Swoboda-Colberg, N., Bleeker, W., Peterson, T.D., Jefferson, C.W., Khudoley, A.K., 2010. In situ U-Pb SIMS (IN-SIMS) micro-baddeleyite dating of mafic rocks: Method with examples. Precambrian Res. 183, 379-387. doi:10.1016/j.precamres.2010.05.004

Chester, F.M., Logan, J.M., 1986. Implications for mechanical properties of brittle faults from observations of the Punchbowl fault zone, California. Pure Appl. Geophys. 124, 79-106. doi:10.1007/BF00875720

Childs, C., Watterson, J., Walsh, J.J., 1996. A model for the structure and development of fault zones. J. Geol. Soc. London. 153, 337-340. doi:10.1144/gsjgs.153.3.0337

Childs, C., Manzocchi, T., Walsh, J.J., Bonson, C.G., Nicol, A., Schöpfer, M.P.J., 2009. A geometric model of fault zone and fault rock thickness variations. J. Struct. Geol. 31, 117127. doi:https://doi.org/10.1016/j.jsg.2008.08.009

Chi, G., Haid, T., Quirt, D., Fayek, M., Blamey, N., Chu, H., 2017. Petrography, fluid inclusion analysis, and geochronology of the End uranium deposit, Kiggavik, Nunavut, Canada. Miner. Depos. 52, 211-232. doi:10.1007/s00126-016-0657-9

Cuney, M.L., 2005. World-class unconformity-related uranium deposits: Key factors for their genesis, in: Mao, J., Bierlein, F.P. (Eds.), Mineral Deposit Research: Meeting the Global Challenge: Proceedings of the Eighth Biennial SGA Meeting Beijing, China, 18-21 August 
2005. Springer Berlin Heidelberg, Berlin, Heidelberg, pp. 245-248. doi:10.1007/3-54027946-6_64

Dahlkamp, F., J., 1993. Uranium ore deposits. Springer-Verlag, Berlin, 460 p.

Davis, W.J., Hanmer, S., Tella, S., Sandeman, H., Ryan, J.J., 2006. U-Pb Geochronology of the MacQuoid supracrustal belt and Cross Bay plutonic complex: key components of the northwestern Hearne subdomain, Western Churchill Province, Nunavut, Canada. Precambrian Research 145, 53-80.

Davis, W.J., Gall, Q., Jefferson, C.W., Rainbird, R.H., 2011. Fluorapatite in the Paleoproterozoic Thelon Basin: Structural-stratigraphic context, in situ ion microprobe U-Pb ages, and fluidflow history. GSA Bull. 123, 1056-1073. doi:10.1130/B30163.1

De Veslud, C.L.C., Cuney, M., Lorilleux, G., Royer, J.-J., Jébrak, M., 2009. 3D Modeling of Uranium-bearing Solution-collapse Breccias in Proterozoic Sandstones (Athabasca Basin, Canada)-Metallogenic Interpretations. Comput. Geosci. 35, 92-107. doi:10.1016/j.cageo.2007.09.008

Devoto, R.H., 1978. Uranium in Phanerozoic sandstone and volcanic rocks. Short course in uranium deposits; their mineralogy and origin. Mineralogical Association of Canada, Short Course Handbook 3, 293-305

Dieng, S., Kyser, K., Godin, L., 2013. Tectonic history of the North American shield recorded in uranium deposits in the Beaverlodge area, northern Saskatchewan, Canada. Precambrian Res. 224, 316-340. doi:10.1016/j.precamres.2012.09.011

Dong, G., Morrison, G., Jaireth, S., 1995. Quartz textures in epithermal veins, Queensland; classification, origin and implication. Econ. Geol. 90, 1841-1856. doi:10.2113/gsecongeo.90.6.1841

Eriksson, P.G., Martins-Neto, M.A., Nelson, D.R., Aspler, L.B., Chiarenzelli, J.R., Catuneanu, O., Sarkar, S., Altermann, W., Rautenbach, C.J.D.W., 2001. An introduction to Precambrian basins; their characteristics and genesis; The influence of magmatism, tectonics, sea level change and paleo-climate on Precambrian basin evolution; change over time. Sediment. Geol. doi:10.1016/S0037-0738(01)00066-5

Farkas, A., 1984. Mineralogy and host rock alteration of the Lone Gull deposit: Urangesellschaft internal report, $44 \mathrm{p}$.

Faulkner, D.R., Jackson, C.A.L., Lunn, R.J., Schlische, R.W., Shipton, Z.K., Wibberley, C.A.J., Withjack, M.O., 2010. A review of recent developments concerning the structure, mechanics and fluid flow properties of fault zones. J. Struct. Geol. 32, 1557-1575. doi:10.1016/j.jsg.2010.06.009 
Fayek, M., Kyser, T.K., 1997. Characterization of multiple fluid-flow events and rare-earthelement mobility associated with formation of unconformity-type uranium deposits in the Athabasca Basin, Saskatchewan. Can. Mineral. 35, 627-658

Fayek, M., Quirt, D., Jefferson, C., Camacho, A., Ashcroft, G., Shabaga, B., Sharpe, R. 2017. The Kiggavik-Andrew Lake structural trend uranium deposits: an overview. In SGA Extended Abstract proceedings. SGA 2017 Conference Quebec City, August 20-23. In press.

Friedrich, G., Weyer, H.J., and Bechtel, A. 1989. The Lone Gull uranium deposit - New geochemical and petrological data as evidence for the nature of the ore-bearing solutions. In: Proceedings of an IAEA Technical Committee Meeting on Metallogenesis of Uranium Deposits, March 9-12 1987, IAEA TC-542/19, p. 293-306

Fuchs, H., and Hilger, W., 1989. Kiggavik (Lone Gull): An unconformity related uranium deposit in the Thelon basin, Northwest Territories, Canada: International Atomic Energy Agency Technical Committee Meeting, Saskatoon, 1-3 September 1987, IAEA TECDOC-500, p. 429-454

Fuchs, H.D., Hilger, W., and Prosser, E., 1986. Geology and exploration history of the Lone Gull property, in Evans, L., ed., Uranium Deposits of Canada: Canadian Institute of Mining and Metallurgy Special Volume 33, p. 286-292

Gall, Q., Peterson, T.D., Donaldson, J., 1992. A proposed revision of Early Proterozoic stratigraphy of the Thelon and Baker Lake basins, Northwest Territories. Geol. Surv. Canada Curr. Res. 92-1c, 129-137.

Gandhi, S.S., Potter, E.G., and Fayek, M., 2013. Polymetallic U-Ag veins at Port Radium, Great Bear magmatic zone, Canada: main botryoidal pitchblende stage cuts $1.74 \mathrm{Ga}$ diabase dykes and has REE signatures diagnostic of unconformity-type deposits; Geol. Surv. Canada, Open File 7493

Grare, A., Benedicto, A., Lacombe, O., Trave, A., Ledru, P., Robbins, J., and Blains, M., 2017. Structural controls on uranium mineralization at the Kiggavik Project (NE Thelon area, Canada). In SGA Extended abstract proceedings of the 14th Biennial SGA Meeting, Quebéc, Canada, Volume 2. p739. SGA 2017 Conference in Quebec City, August 20-23. ISBN: 978-2-9816898-0-1

Györfi, I., Hajnal, Z., White, D.J., Takacs, E., Reilkoff, B., Annesley, I.R., Powell B., and Koch, R., 2007. High resolution seismic survey from the McArthur River region; contributions to mapping the complex P2 uranium ore zone, Athabasca Basin Saskatchewan, EXTECH IV: Geology and Uranium Exploration Technology of the Proterozoic Athabasca Basin, 
Saskatchewan and Alberta, Edit. C. W. Jefferson, and G. Delaney; GSC Bull. 588; SGS Special Pub. 18; GAC (Mineral Deposits Division) Special Pub. 4; 397-412

Hadlari, T., and Rainbird, R.H., 2011. Retro-arc extension and continental rifting: a model for the Paleoproterozoic Baker Lake Basin, Nunavut1Geological Survey of Canada Contribution 20100436. Can. J. Earth Sci. 48, 1232-1258. doi:10.1139/e11-002

Hanmer, S., Williams, M., Kopf, C., 1995. Striding-Athabasca mylonite zone: implications for the Archean and Early Proterozoic tectonics of the western Canadian Shield. Can. J. Earth Sci. 32, 178-196. doi:10.1139/e95-015

Heaman, L.M., LeCheminant, A.N., 1993. Paragenesis and U-Pb systematics of baddeleyite (ZrO2). Chem. Geol. 110, 95-126. doi:http://dx.doi.org/10.1016/0009-2541(93)90249-I

Hiatt, E.E., Kyser, K., Dalrymple, R.W., 2003. Relationships among sedimentology, stratigraphy, and diagenesis in the Proterozoic Thelon Basin, Nunavut, Canada: Implications for paleoaquifers and sedimentary-hosted mineral deposits. J. Geochemical Explor. 80, 221240. doi:10.1016/S0375-6742(03)00192-4

Hoeve, J., and Sibbald, T.I.I., 1978. On the genesis of Rabbit Lake and other unconformity-type uranium deposits in Northern Saskatchewan, Canada. Econ. Geol. 73, 1450-1473

Hoeve, J., and Quirt, D., 1984. Mineralization and host-rock alteration in relation to clay mineral diagenesis and evolution of the Middle-Proterozoic, Athabasca Basin, northern Saskatchewan, Canada, Saskatchewan Research Council Technical Report, 187 pp.

Hoffman, P.F., 1988. United Plates of America, the Birth of a Craton: Early Proterozoic Assembly and Growth of Laurentia. Annu. Rev. Earth Planet. Sci. 16, 543-603. doi:10.1146/annurev.ea.16.050188.002551

Jaireth, S., Roach, I.C., Bastrakov, E., Liu, S., 2016. Basin-related uranium mineral systems in Australia: A review of critical features. Ore Geol. Rev. 76, 360-394. doi:https://doi.org/10.1016/j.oregeorev.2015.08.006

Jefferson, C.W., Thomas, D.J., Gandhi, S.S., Ramaekers, P., Delaney, G., Brisbin, D., Cutts, C., Quirt, D., Portella, P., and Olson, R.A., 2007. Unconformity-Associated Uranium Deposits of the Athabasca Basin, Saskatchewan and Alberta. In: Goodfellow, W.D. (Ed.), Mineral Deposits of Canada: A Synthesis Of Major Deposit Types, District Metallogeny, The Evolution Of Geological Provinces, And Exploration Methods. Geological Assoiciation of Candada, Special Publication 5, pp. 273-305

Jefferson, C.W., Chorlton, L.B., Pehrsson, S.J., Peterson, T., Wollenberg, P., Scott, J., Tschirhart, V., McEwan, B., Bethune, K., Calhoun, L., White, J.C., Leblon, B., LaRocque, A., Shelat, Y., Lentz, D., Patterson, J., Riegler, T., Skulski, T., Robinson, S., Paulen, R., 
McClenaghan, B., Layton-Matthews, D., Maclsaac, D., Riemer, W., Stieber, C. and Tschirhart, P. 2011a. Northeast Thelon Region: 77 Geomapping for Uranium in Nunavut. Geological Survey of Canada, Open File 6862

Jefferson, C.W., Pehrsson, S., Peterson, T., Chorlton, L., Davis, W., Keating, P., Gandhi, S., Fortin, R., Buckle, J., Miles, W., Rainbird, R., LeCheminant, A., Tschirhart, V., Tschirhart, P., Morris, W., Scott, J., Cousens, B., McEwan, B., Bethune, K., Riemer, W., Calhoun, L., White, J., Maclsaac, D., Leblon, B., Lentz, D., LaRocque, A., Shelat, Y., Patterson, J., Enright, A., Stieber, C., Riegler, T. 2011b. Northeast Thelon region geoscience framework new maps and data for uranium in Nunavut. Geological Survey of Canada, Open File 6950. doi: $10.4095 / 288791$

Johnstone, D., Bethune, K.M., Quirt, D., Benedicto, A. 2017. Lithostratigraphic and structural controls of uranium mineralization in the Kiggavik East, Centre and Main Zone deposits, Nunavut. In Proceedings of the Geological Association of Canada-Mineralogical Association of Canada, Joint Annual Meeting, Whitehorse Yukon, June 1-3 2016

Kyser, K. and Cuney, M., 2015. Geology and geochemistry of uranium and thorium deposits. Edited by Michel Cuney, Kurt Kyser (2015) 362 pp. ISBN 978-0-921294-57-3

LeCheminant, A.N., Heaman, L.M., 1989. Mackenzie igneous events, Canada: Middle Proterozoic hotspot magmatism associated with ocean opening. Earth Planet. Sci. Lett. 96, 38-48. doi:http://dx.doi.org/10.1016/0012-821X(89)90122-2

Lunn, R.J., Willson, J.P., Shipton, Z.K., Moir, H., 2008. Simulating brittle fault growth from linkage of preexisting structures. J. Geophys. Res. Solid Earth 113, n/a--n/a. doi:10.1029/2007JB005388

McEwan, B. 2012. Structural style and regional comparison of the Ketyet River group northeast of Baker Lake, Nunavut. M.Sc. Thesis, University of Regina

MacRae, C.M., Wilson, N.C., Torpy, A., 2013. Hyperspectral cathodoluminescence. Mineral. Petrol. 107, 429-440. doi:10.1007/s00710-013-0272-8

Mercadier, J., Cuney, M., Cathelineau, M., Lacorde, M., 2011. U redox fronts and kaolinisation in basement-hosted unconformity-related $U$ ores of the Athabasca Basin (Canada): late $U$ remobilisation by meteoric fluids. Miner. Depos. 46, 105-135. doi:10.1007/s00126-0100314-7

Meunier, J.D., Sellier, E., Pagel, M., 1990. Radiation-damage rims in quartz from uraniumbearing sandstones. J. Sediment. Res. 60, 53-58. doi:10.1306/212F910B-2B24-11D78648000102C1865D 
Miller, A.R., 1980. Uranium geology of the Eastern Baker Lake basin, district of Keewatin, Northwest Territories. Geological survey of Canada, bulletin 330,63p.

Miller, A.R. and LeCheminant, A.N., 1985. Geology and uranium metallogeny of Proterozoic supracrustal successions, central District of Keewatin, N.W.T., with comparisons to northern Saskatchewan. Special Volume - Canadian Institute of Mining and Metallurgy 32: 167-185

Mills, A.J., Berman, R.G., Davis, W.J., Tella, S., Roddick, C., S. Carr, S.H., 2007. Thermobarometry and geochronology of the Uvauk complex, a polymetamorphic Neoarchean and Paleoproterozoic segment of the Snowbird tectonic zone, Nunavut, Canada. Can. J. Earth Sci. 44, 245-266. doi:10.1139/e06-080

Moncada, D., Mutchler, S., Nieto, A., Reynolds, T.J., Rimstidt, J.D., Bodnar, R.J., 2012. Mineral textures and fluid inclusion petrography of the epithermal $\mathrm{Ag}-\mathrm{Au}$ deposits at Guanajuato, Mexico: Application to exploration. J. Geochemical Explor. 114, 20-35. doi:https://doi.org/10.1016/j.gexplo.2011.12.001

OECD NEA \& IAEA, 2016. Uranium 2016: Resources, Production and Demand A Joint Report by the OECD Nuclear Energy Agency and the International Atomic Energy Agency English, 504 p, available online at : https://www.oecd-nea.org/ndd/pubs/2016/7301-uranium2016.pdf

Percival, J.B., Kodama, H., 1989. Sudoite from Cigar Lake, Saskatchewan. Can. Mineral. 27, 633-641

Percival, J.B., Bell, K., Torrance, J.K., 1993. Clay mineralogy and isotope geochemistry of the alteration halo at the Cigar Lake uranium deposit. Can. J. Earth Sci. 30, 689-704. doi:10.1139/e93-056

Pehrsson, S., Jefferson, C.W., Peterson, T., Scott, J., Chorlton, L., Hillary, B., Patterson, Judith, Lentz, D., Shelat, Y., and Bethune, K., 2010. Basement to the Thelon Basin, Nunavut Revisited. Special Session on Geological Environments hosting Uranium Deposits, GeoCanada 2010 - Working with the Earth, Calgary, May 10-14th, 4 p. abstract

Pehrsson S., Berman, R., Davis, W. 2013. Paleoproterozoic orogenesis during Nuna aggregation: a case study of reworking of the Archean Rae craton, Woodburn Lake, Nunavut. Precambrian Research, 232: 167-188. doi: 10.1016/j.precamres.2013.02.010

Peterson, T.D., Breemen, O. Van, Sandeman, H., Cousens, B., 2002. Proterozoic (1.85-1.75 $\mathrm{Ga}$ ) igneous suites of the Western Churchill Province: granitoid and ultrapotassic magmatism in a reworked Archean hinterland. Precambrian Res. 119, 73-100. doi:https://doi.org/10.1016/S0301-9268(02)00118-3 
Peterson, T.D., 2006. Geology of the Dubawnt Lake area, Nunavut-Northwest Territories. Geological Survey of Canada, Bulletin 580

Peterson, T.D., Scott, J.M.J., LeCheminant, A.N., Jefferson, C.W., Pehrsson, S.J., 2015a. The Kivalliq Igneous Suite: Anorogenic bimodal magmatism at $1.75 \mathrm{Ga}$ in the western Churchill Province, Canada. Precambrian Res. 262, 101-119. doi:https://doi.org/10.1016/j.precamres.2015.02.019

Peterson, T.D., Scott, J.M.J., Lecheminant, A.N., Tschirhart, V.L., Chorlton, L.B., Davis, W.J., Hamilton, M.A., 2015b. Nueltin granites and mafic rocks in the Tebesjuak Lake map area, Nunavut: new geochronological, petrological, and geophysical data. Geological Survey of Canada, Current Research (Online) 2015-5, 2015; 23 pages, doi:10.4095/296163

Polito, P.A., Kyser, T.K., Rheinberger, G., and Southgate, P.N., 2005a. A paragenetic and isotopic study of the proterozoic Westmoreland uranium deposits, Southern McArthur Basin, Northern Territory, Australia. Econ. Geol. 100, 1243-1260

Polito, P.A., Kyser, T.K., Thomas, D., Marlatt, J., and Drever, G., 2005b. Re-evaluation of the petrogenesis of the Proterozoic Jabiluka unconformity-related uranium deposit, Northern Territory, Australia. Mineral. Deposita 40, 257-288

Potter, E. G., Sharpe, R., Girard, I., Fayek, M., Gammon, P., Quirt, D., and Robbins, J. 2015. Fe and $\mathrm{Mg}$ Signatures of the Bong Uranium Deposit, Thelon Basin, Nunavut. In Targeted Geoscience Initiative 4: unconformity-related uranium systems. Edited by E.G. Potter and D.M. Wright. Geological Survey of Canada, Open File 7791, pp. 52-60

Quirt. D. 2017. Clay mineral host-rock alteration at the Bong basement-hosted uranium deposit, Kiggavik area, Nunavut. In SGA Extended Abstract proceedings. SGA 2017 Conference Quebec City, August 20-23. In press

Rainbird, R.H. and Hadlari, T., 2000. Revised stratigraphy and sedimentology of the Dubawnt Supergroup at the northern margin of the Baker Lake Basin, Nunavut; Geological survey of Canada, Current Research 2000-C8, 9p.

Rainbird, R.H., Hadlari, T., Aspler, L.B., Donaldson, J.A., LeCheminant, A.N., Peterson, T.D., 2003. Sequence stratigraphy and evolution of the paleoproterozoic intracontinental Baker Lake and Thelon basins, western Churchill Province, Nunavut, Canada. Precambrian Res. 125, 21-53. doi:10.1016/S0301-9268(03)00076-7

Rainbird, R.H., Davis, W.J., Stern, R.A., Peterson, T.D., Smith, S.R., Parrish, R.R., Hadlari, T., 2006. Ar-Ar and U-Pb Geochronology of a Late Paleoproterozoic Rift Basin: Support for a Genetic Link with Hudsonian Orogenesis, Western Churchill Province, Nunavut, Canada. J. Geol. 114, 1-17. doi:10.1086/498097 
Rainbird, R.H., Davis, W.J., 2007. U-Pb detrital zircon geochronology and provenance of the late Paleoproterozoic Dubawnt Supergroup: Linking sedimentation with tectonic reworking of the western Churchill Province, Canada. GSA Bull. 119, 314. doi:10.1130/B25989.1

Rainbird, R.H., Davis, W.J., Pehrsson, S.J., Wodicka, N., Rayner, N., Skulski, T., 2010. Early Paleoproterozoic supracrustal assemblages of the Rae domain, Nunavut, Canada: Intracratonic basin development during supercontinent break-up and assembly. Precambrian Res. 181, 167-186. doi:https://doi.org/10.1016/j.precamres.2010.06.005

Ramaekers, P., Jefferson, C.W., Yeo, G.M., Collier, B., Long, D.G.F., Drever, G., et al. 2007. Revised geological map and stratigraphy of the Athabasca Group, Saskatchewan and Alberta. In EXTECH IV: Geology and Uranium Exploration TECHnology of the Proterozoic Athabasca Basin, Saskatchewan and Alberta. Edited by C.W. Jefferson and G. Delaney. Geological Survey of Canada, Bulletin 588, (also Geological Association of Canada, Mineral Deposits Division, Special Publication 4; Saskatchewan Geological Society, Special Publication 18). pp. 155-192

Regan, S.P., Williams, M.L., Leslie, S., Mahan, K.H., Jercinovic, M.J., Holland, M.E., 2014. The Cora Lake shear zone, Athabasca granulite terrane, an intraplate response to far-field orogenic processes during the amalgamation of Laurentia. Can. J. Earth Sci. 51, 877-901. doi:10.1139/cjes-2014-0015

Renac, C., Kyser, T.K., Durocher, K., Dreaver, G., O'Connor, T., 2002. Comparison of diagenetic fluids in the Proterozoic Thelon and Athabasca Basins, Canada: implications for protracted fluid histories in stable intracratonic basins. Can. J. Earth Sci. 39, 113-132. doi:10.1139/e01-077

Richard, A., Rozsypal, C., Mercadier, J., Banks, D. a., Cuney, M., Boiron, M.-C., Cathelineau, M., 2011. Giant uranium deposits formed from exceptionally uranium-rich acidic brines. Nat. Geosci. 5, 142-146. doi:10.1038/ngeo1338

Riegler, T., Quirt, D., Beaufort, D., 2016a. Spatial distribution and compositional variation of APS minerals related to uranium deposits in the Kiggavik-Andrew Lake structural trend, Nunavut, Canada. Miner. Depos. 51, 219-236. doi:10.1007/s00126-015-0595-y

Riegler, T., Beaufort, M.-F., Allard, T., Pierson-Wickmann, A.C., Beaufort, D., 2016b. Nanoscale relationship between uranium and carbonaceous material in alteration haloes around unconformity-related uranium deposits of the Kiggavik camp, Paleoproterozoic Thelon Basin, Nunavut, Canada. Ore Geol. Rev. 79, 382-391. doi:https://doi.org/10.1016/j.oregeorev.2016.04.018 
Robbins, J., Richard, Y., Carter, C. Behaegel, M., Benedicto, A. and Ledru, P. 2015. New guides led to new models - Continuing return of exploration experience, Nunavut, Canada. In The AusIMM International Uranium Conference 2015, Abstract volume, p. 2

Ross, G.M., Eaton, D.W., Boerner, D.E., Miles, W., 2000. Tectonic entrapment and its role in the evolution of continental lithosphere: An example from the Precambrian of western Canada. Tectonics 19, 116-134. doi:10.1029/1999TC900047

Roy, R., Benedicto, A., Grare, A., Béhaegel, M., Yoann, R., Grant, H. 2017. 3D gravity modelling applied to the exploration of uranium unconformity-related basement hosted deposits: the Contact prospect case study, Kiggavik, NE Thelon region (Nunavut, Canada) Can. J. Earth Sci. doi: 10.1139/cjes-2016-0225

Ruzicka, V.R., 1989. Monometallic and polymetallic deposits associated with the sub-Athabasca unconformity in Saskatchewan, in Current Research: Geological Survey of Canada, Paper 89-1C, p. 67-79

Ruzicka, V.R., 1996. Unconformity-associated uranium, Chapter 7 in Eckstrand, O.R., Sinclair, W.D., and Thorpe, R.I., 1995. Geology of Canadian Mineral Deposit Types: Geological Survey of Canada, Geology of Canada, v, 8, p. 197-210

Sanborn-Barrie, M., Carr, S., Thériault, R., 2001. Geochronological constraints on metamorphism, magmatism and exhumation of deep-crustal rocks of the Kramanituar Complex, with implications for the Paleoproterozoic evolution of the Archean western Churchill Province, Canada. Contrib. to Mineral. Petrol. 141, 592-612. doi:10.1007/s004100100262

Scott, J.M.J., Peterson, T.D. and McCurdy, M.W., 2012. U, Th, and REE occurrences within Nueltin Granite at Nueltin Lake, Nunavut: Recent Observations. Geological Survey of Canada, Paper 2012-1, pp. 1-11

Scott, J.M.J., Peterson, T.D., Jefferson, C.W., Cousens, B.L., 2015. Petrology and geochronology of Paleoproterozoic intrusive rocks, Kiggavik uranium camp, Nunavut. Can. J. Earth Sci. 518, 1-80. doi:10.1139/cjes-2014-0153

Shabaga, B., M., Fayek, M., Quirt, D., Davis, B., Pesja, T., Jefferson, C., 2015. Geochemistry and Geochronology of the Andrew Lake deposit, Thelon Basin, Nunavut, Canada. Poster presented at 2015 GAC MAC

Shabaga, B., M., Fayek, M., Quirt, D., Jefferson, C.W., Camacho, A., 2017a. Geochronology and genesis of the Andrew Lake uranium deposit, Thelon Basin, Nunavut, Canada. Poster presented at 2017 GAC MAC 
Shabaga, B.M., Fayek, M., Quirt., D., Jefferson, C. 2017b. Geochronology of the Kiggavik uranium deposit, Thelon Basin, Canada. In SGA Extended Abstract proceedings. SGA 2017 Conference Quebec City, August 20-23. In press

Sharpe, R., Fayek, M., Quirt, D., Jefferson, C.W., 2015. Geochronology and genesis of the bong uranium deposit, Thelon Basin, Nunavut, Canada. Econ. Geol. 110, 1759-1777. doi:10.2113/econgeo.110.7.1759

Sheahan, C., Fayek, M., Quirt, D., Jefferson, C.W., 2015. A Combined Ingress-Egress Model for the Kianna Unconformity-Related Uranium Deposit, Shea Creek Project, Athabasca Basin, Canada. Econ. Geol. 111, 225. doi:10.2113/econgeo.111.1.225

Simmons, S.F., Christenson, B.W., 1994. Origins of calcite in a boiling geothermal system. Am. J. Sci. 294, 361-400. doi:10.2475/ajs.294.3.361

Skirrow, R.G., Mercadier, J., Armstrong, R., Kuske, T., Deloule, E., 2016. The Ranger uranium deposit, northern Australia: Timing constraints, regional and ore-related alteration, and genetic implications for unconformity-related mineralisation. Ore Geol. Rev. 76, 463-503. doi:https://doi.org/10.1016/j.oregeorev.2015.09.001

Tourigny, G., Quirt, D.H., Wilson, N.S.F., Wilson, S., Breton, G., and Portella, P., 2007. Geological and structural features of the Sue C uranium deposit, McClean Lake area, Saskatchewan, inJefferson, C.W., and Delaney, G., eds., EXTECH IV: Geology and Uranium EXploration TECHnology of the Proterozoic Athabasca Basin, Saskatchewan and Alberta: Geological Survey of Canada, Bulletin 588, p. 229-247 (also Geological Association of Canada, Mineral Deposits Division, Special Publication 4; Saskatchewan Geological Society, Special Publication 18)

Tschirhart, V., Morris, W.A., Jefferson, C.W., 2013. Framework geophysical modelling of granitoid vs. supracrustal basement to the northeast Thelon Basin around the Kiggavik uranium camp, Nunavut. Can. J. Earth Sci. 50, 667-677. doi:10.1139/cjes-2012-0149

Tschirhart, V., Jefferson, C.W., Morris, W.A. 2017. Basement geology beneath the northeast Thelon Basin, Nunavut: insights from integrating new gravity, magnetic and geological data. Geophysical Prospecting, 65: 617-636. doi: 10.1111/1365-2478.12430

Turner, W.A. 2000. Geology and geochemistry of the Mallery Lake precious metal-bearing epithermal system, Nunavut, Canada. MSc Thesis, Univ Alberta, 176 pp.

Turner, W.A., Richards, J., Nesbitt, B., Muehlenbachs, K., Biczok, J., 2001. Proterozoic lowsulfidation epithermal Au-Ag mineralization in the Mallery Lake area, Nunavut, Canada. Miner. Depos. 36, 442-457. doi:10.1007/s001260100181 
Turner, W.A., Heaman, L.M., Creaser, R.A., 2003. Sm-Nd fluorite dating of Proterozoic lowsulfidation epithermal $\mathrm{Au}-\mathrm{Ag}$ deposits and $\mathrm{U}-\mathrm{Pb}$ zircon dating of host rocks at Mallery Lake, Nunavut, Canada. Can. J. Earth Sci. 40, 1789-1804. doi:10.1139/e03-061

Van Breemen, O., Peterson, T.D., Sandeman, H.A., 2005. U-Pb zircon geochronology and Nd isotope geochemistry of Proterozoic granitoids in the western Churchill Province: intrusive age pattern and Archean source domains. Can. J. Earth Sci. 42, 339-377. doi:10.1139/e05-007

Van der Zee, W., Wibberley, C.A.J., Urai, J.L., 2008. The influence of layering and pre-existing joints on the development of internal structure in normal fault zones: the Lodève basin, France. Geol. Soc. London, Spec. Publ. 299, 57-74. doi:10.1144/SP299.4

Wallis, R.H., Saracoglu, N., Brummer, J.J., and Golighltly, J.P.1985. The geology of the McClean uranium deposits, northern Saskatchewan; inSibbald, T.I.I. and Petruk, W. (eds.), Geology of Uranium Deposits, CIM Spec. Vol. 32, p. 101-131

Wibberley, C.A.J., Yielding, G., Di Toro, G., 2008. Recent advances in the understanding of fault zone internal structure: a review. Geol. Soc. London, Spec. Publ. 299, 5-33. doi:10.1144/SP299.2

Wilde, A.R., and Wall, V.J., 1987. Geology of the NabarlekUranium Deposit, NorthernTerritory. Australia. Econ. Geol. Vol. 82, 1152-1168

Williams-Jones, A.E., Sawiuk, M.J., 1985. The Karpinka Lake uranium prospect, Saskatchewan; a possible metamorphosed middle Precambrian sandstone-type uranium deposit. Econ. Geol. 80, 1927-1941. doi:10.2113/gsecongeo.80.7.1927

Williams, J.H., Johnson, C.D., 2004. Acoustic and optical borehole-wall imaging for fracturedrock aquifer studies. J. Appl. Geophys. 55, 151-159. doi:https://doi.org/10.1016/j.jappgeo.2003.06.009

Weyer H..J, Friedrich G., Bechtel A., Ballhorn R.K., 1987. The Lone Gull uranium deposit-new geochemical and petrological data as evidence for the nature of the ore bearing solutions. Metallogenesis of uranium deposits: Proceeding of a technical committee meeting, Vienna, p. $9-12$

Zaleski, E., Pehrsson, S., Duke, N., Davis, W.J., L'Heureux, R., Greiner, E., Kerswill, J.A., 2000. Quartzite sequences and their relationships, Woodburn Lake group, western Churchill Province, Nunavut. Geological Survey of Canada, Current Research (Online) no. 2000-C7, 2000; 10 p., doi:10.4095/211098 